\title{
LIVAS: a 3-D multi-wavelength aerosol/cloud database based on CALIPSO and EARLINET
}

\author{
V. Amiridis ${ }^{1}$, E. Marinou ${ }^{1,2}$, A. Tsekeri ${ }^{1}$, U. Wandinger $^{3}$, A. Schwarz ${ }^{3}$, E. Giannakaki ${ }^{4}$, R. Mamouri ${ }^{5}$, P. Kokkalis ${ }^{1}$, \\ I. Binietoglou ${ }^{6}$, S. Solomos ${ }^{1}$, T. Herekakis ${ }^{1}$, S. Kazadzis ${ }^{7}$, E. Gerasopoulos ${ }^{8}$, E. Proestakis ${ }^{1,8}$, M. Kottas ${ }^{1}$, D. Balis ${ }^{2}$, \\ A. Papayannis ${ }^{9}$, C. Kontoes ${ }^{1}$, K. Kourtidis ${ }^{10}$, N. Papagiannopoulos ${ }^{11}$, L. Mona ${ }^{11}$, G. Pappalardo ${ }^{11}$, O. Le Rille ${ }^{12}$, and \\ A. Ansmann ${ }^{3}$ \\ ${ }^{1}$ Institute for Astronomy, Astrophysics, Space Applications and Remote Sensing, National Observatory of Athens, \\ Athens 15236, Greece \\ ${ }^{2}$ Aristotle University of Thessaloniki, Thessaloniki, Greece \\ ${ }^{3}$ Leibniz Institute for Tropospheric Research (TROPOS), Leipzig, Germany \\ ${ }^{4}$ Finnish Meteorological Institute, Kuopio Unit, Helsinki, Finland \\ ${ }^{5}$ Cyprus University of Technology, Limassol, Cyprus \\ ${ }^{6}$ National Institute of R\&D for Optoelectronics, Bucharest, Romania \\ ${ }^{7}$ Physikalisch-Meteorologisches Observatorium Davos, World Radiation Center, Davos, Switzerland \\ ${ }^{8}$ Institute of Environmental Research and Sustainable Development, National Observatory of Athens, Greece \\ ${ }^{9}$ National Technical University of Athens, Zografou, Greece \\ ${ }^{10}$ School of Engineering, Democritus University of Thrace, Xanthi, Greece \\ ${ }^{11}$ Istituto di Metodologie per l'Analisi Ambientale, Consiglio Nazionale delle Ricerche, Potenza, Italy \\ ${ }^{12}$ ESA/ESTEC, Postbus 299, 2200-AG Noordwijk, the Netherlands
}

Correspondence to: V. Amiridis (vamoir@noa.gr)

Received: 18 December 2014 - Published in Atmos. Chem. Phys. Discuss.: 23 January 2015

Revised: 29 May 2015 - Accepted: 31 May 2015 - Published: 01 July 2015

\begin{abstract}
We present LIVAS (LIdar climatology of Vertical Aerosol Structure for space-based lidar simulation studies), a 3-D multi-wavelength global aerosol and cloud optical database, optimized to be used for future space-based lidar end-to-end simulations of realistic atmospheric scenarios as well as retrieval algorithm testing activities. The LIVAS database provides averaged profiles of aerosol optical properties for the potential spaceborne laser operating wavelengths of $355,532,1064,1570$ and $2050 \mathrm{~nm}$ and of cloud optical properties at the wavelength of $532 \mathrm{~nm}$. The global database is based on CALIPSO observations at 532 and $1064 \mathrm{~nm}$ and on aerosol-type-dependent backscatter- and extinction-related Ångström exponents, derived from EARLINET (European Aerosol Research Lidar Network) groundbased measurements for the UV and scattering calculations for the IR wavelengths, using a combination of input data from AERONET, suitable aerosol models and recent literature. The required spectral conversions are calculated for
\end{abstract}

each of the CALIPSO aerosol types and are applied to CALIPSO backscatter and extinction data corresponding to the aerosol type retrieved by the CALIPSO aerosol classification scheme. A cloud optical database based on CALIPSO measurements at $532 \mathrm{~nm}$ is also provided, neglecting wavelength conversion due to approximately neutral scattering behavior of clouds along the spectral range of LIVAS. Averages of particle linear depolarization ratio profiles at $532 \mathrm{~nm}$ are provided as well. Finally, vertical distributions for a set of selected scenes of specific atmospheric phenomena (e.g., dust outbreaks, volcanic eruptions, wild fires, polar stratospheric clouds) are analyzed and spectrally converted so as to be used as case studies for spaceborne lidar performance assessments. The final global data set includes 4-year (1 January 2008-31 December 2011) time-averaged CALIPSO (CloudAerosol Lidar and Infrared Pathfinder Satellite Observations) data on a uniform grid of $1^{\circ} \times 1^{\circ}$ with the original high vertical resolution of CALIPSO in order to ensure realistic 
simulations of the atmospheric variability in lidar end-to-end simulations.

\section{Introduction}

A general methodology to test the ability of candidate future spaceborne remote-sensing instruments to observe atmospheric quantities is the application of their processing algorithms on simulated data sets. The data sets are usually based on the instrument characteristics and a description of the atmospheric state. Especially for active remote sensors as lidars, the vertical dimension should be included in the simulations. Global distributions of such data are available today due to the launch of the Cloud-Aerosol Lidar with Orthogonal Polarization (CALIOP) instrument on board the CloudAerosol Lidar and Infrared Pathfinder Satellite Observations (CALIPSO) mission of NASA/CNES in June 2006 (Winker et al., 2009). Ever since, CALIPSO provides global aerosol and cloud vertical distributions to the scientific community through analysis of CALIOP backscatter observations at the operating wavelengths of 532 and $1064 \mathrm{~nm}$.

The technique of active remote sensing of the atmosphere by lidar has been also chosen for two of the future ESA Earth Explorer Missions, namely the Atmospheric Dynamics Mission Aeolus (ADM-Aeolus; Stoffelen et al., 2005) and the Earth Clouds, Aerosols and Radiation Explorer (EarthCARE; ESA, 2004; Illingworth et al., 2014), and was further proposed for the Advanced Space Carbon and Climate Observation of Planet Earth (A-SCOPE), one of the candidates for the 7th Earth Explorer mission. Atmospheric Laser Doppler Instrument (ALADIN) on board ADM-Aeolus and ATmospheric LIDar (ATLID) on board EarthCARE are two high spectral resolution lidars (HSRLs) operating at $355 \mathrm{~nm}$ and detecting the backscatter signal from atmospheric aerosols, clouds and molecules in order to retrieve the horizontal component of the wind vector with Doppler techniques (ALADIN) and the vertical profiles of aerosol and cloud backscatter, extinction and particle depolarization (ATLID). The instrument design proposed for the A-SCOPE mission is an integrated path differential absorption (IPDA) lidar, aiming at measuring column-averaged dryair $\mathrm{CO}_{2}$ mixing ratios with high precision and low bias error, based on short-wave infrared (SWIR) (1570 or $2050 \mathrm{~nm}$ ) laser and detector technologies.

The ESA Reference Atmosphere Model (RMA) currently used for the design and the performance validation of ALADIN and ATLID instruments is derived from airborne lidar measurements performed at $10.6 \mu$ m over regions of the Atlantic during a relatively clean atmospheric period (19881990; Vaughan et al., 1998). This RMA consists of five statistical aerosol backscatter profiles organized by percentiles and one molecular profile with a resolution of $0.5 \mathrm{~km}$ from 0 to $16 \mathrm{~km}$ altitude. ESA RMA provides also the optical prop- erties of various clouds and the albedos for different surface types (sea/land/ice).

Due to its spatial restrictions, the current ESA RMA is not representative for global simulations. The correct performance assessment of current and future ESA lidar instruments requires the development of a refined aerosol and cloud optical database with high spatial resolution for the planetary boundary layer (PBL), the free troposphere (FT) and the stratosphere. An appropriate RMA should be representative of both statistical atmospheric information (i.e., per atmospheric region, climate zone and season) and deterministic information (i.e., extended atmospheric scenes with, e.g., Saharan dust events, biomass-burning aerosol events, volcanic eruption events, polar stratospheric cloud events, convective cloud events). Moreover, the RMA should include multi-wavelength parameters so as to cover the spectral domain of future HSRL and IPDA lidar missions, specifically the three harmonic operating wavelengths of Nd:YAG (neodymium-doped yttrium aluminium garnet) lasers (355, 532 and $1064 \mathrm{~nm}$ ) and typical wavelengths of future IPDA lidars in the SWIR spectral domain $(1.57$ and $2.05 \mu \mathrm{m})$.

Over the recent years, the European Aerosol Research Lidar Network (EARLINET, http://www.earlinet.org/; Bösenberg et al., 2003; Pappalardo et al., 2014) and the Aerosol Robotic Network (AERONET, http://aeronet.gsfc.nasa.gov/; Holben et al., 1998) ground-based lidar and sun photometer networks, respectively, along with the CALIPSO backscatter lidar mission have provided new resources that can be used for the elaboration of such a multi-wavelength database for typical laser operating wavelengths. Additionally, several airborne and ground-based field experiments involving in situ instrumentation together with HSRL and multi-wavelength Raman lidar systems have been performed over the last 20 years and can be very useful for the consolidation of such a RMA.

In this paper we present the LIdar climatology of Vertical Aerosol Structure for space-based lidar simulation studies (LIVAS), which is a RMA aiming to provide profiles of aerosol and cloud optical properties on a global scale that can be used for the simulation of realistic atmospheric scenarios in current and future lidar end-to-end simulations and retrieval algorithm testing activities. For HSRL and IPDA lidar applications, LIVAS addresses the wavelength dependency of aerosol optical properties for the following laser operating wavelengths: 355, 532, $1064 \mathrm{~nm}, 1.57$ and $2.05 \mu \mathrm{m}$. Moreover, LIVAS includes regional and seasonal statistics of aerosol and cloud extensive and intensive optical properties in terms of backscatter coefficient, extinction coefficient and particle linear depolarization ratio. Furthermore, vertical profiles of extensive and intensive optical properties referring to specific atmospheric scenes for a set of selected scenarios are provided (i.e., Saharan dust, smoke from biomass burning, ash from volcano eruptions, polar stratospheric clouds). The data used for the development of LIVAS are presented in Sect. 2 while the methodologies followed 
are given in Sect. 3. The LIVAS product and its validation are presented in Sect. 4, and the paper closes with our conclusions in Sect. 5.

\section{Data}

\subsection{The CALIPSO Level 2 (L2) product}

CALIOP, the principal instrument on board the CALIPSO satellite, part of the NASA A-Train, is a standard dualwavelength (532 and $1064 \mathrm{~nm}$ ) backscatter lidar, operating a polarization channel at $532 \mathrm{~nm}$ (Winker et al., 2009). CALIOP has been acquiring high-resolution profiles of the attenuated backscatter of aerosols and clouds at 532 and $1064 \mathrm{~nm}$ along with polarized backscatter in the visible channel since 2006 (Winker et al., 2009). The horizontal resolution of CALIOP is one-third of a kilometer while the vertical resolution for the observations at $532 \mathrm{~nm}$ is $30 \mathrm{~m}$ from the surface to $8.3 \mathrm{~km}$ height, $60 \mathrm{~m}$ from 8.3 to $20.2 \mathrm{~km}$ height, and $180 \mathrm{~m}$ from 20.2 to $30.1 \mathrm{~km}$ height. For $1064 \mathrm{~nm}$ it is $60 \mathrm{~m}$ from the surface to $20.2 \mathrm{~km}$ height and $180 \mathrm{~m}$ from 20.2 to $30.1 \mathrm{~km}$ height. This data is distributed as part of CALIPSO Level 1 (L1) product.

After calibration and range correction, cloud and aerosol layers are identified and aerosol backscatter and extinction at 532 and $1064 \mathrm{~nm}$ are retrieved as part of the Level 2 product. The product is produced by the application of a succession of algorithms that are described in detail in a special issue of the Journal of Atmospheric and Oceanic Technology (e.g., Winker et al., 2009). In brief, the CALIOP Level 2 retrieval scheme is composed of feature detection and subtyping algorithms (modules that classify features) and an extinction retrieval algorithm that estimates the aerosol backscatter and extinction coefficient profile and total column aerosol optical depth (AOD) using an assumed lidar ratio (LR) for each detected aerosol layer (the LR can be also calculated in cases when clear air is available both above and below a layer (Young and Vaughan, 2009)). The final CALIPSO Level 2 product includes the vertical location of layers (Vaughan et al., 2009), the discrimination of aerosol layers from clouds (Liu et al., 2009), the categorization of the aerosol layers in six subtypes (dust, marine, smoke, polluted dust, polluted continental, and clean continental; Omar et al., 2009), and the AOD estimations for each layer detected (Young and Vaughan, 2009). Due to CALIOP's sensitivity to polarization at $532 \mathrm{~nm}$, the depolarization from non-spherical dust particles serves as an independent means of discrimination between dust and other aerosol species. In this study we used the Version 3 of the Level 2 product (Young and Vaughan, 2009).

\subsection{The EARLINET product}

EARLINET has been operating since 2000 and aims at establishing a quantitative and comprehensive database for the aerosol vertical, spatial and temporal distribution of aerosols on the European continental scale (Pappalardo et al., 2014). To date, EARLINET includes 27 stations in 16 countries performing lidar observations on a regular schedule of one daytime measurement per week around noon and two nighttime measurements per week with low background light in order to perform Raman extinction measurements (see Table 1 in Pappalardo et al., 2014). The first volumes of the EARLINET database have been published in biannual volumes at the World Data Center for Climate (The EARLINET publishing group 2000-2010, 2014a, b). In addition to the routine measurements, further observations are devoted to monitor special events such as Saharan dust outbreaks, forest fires and volcano eruptions (The EARLINET publishing group 2000 2010, 2014d, e). Moreover, since 14 June 2006 EARLINET has carried out collocated measurements with CALIPSO during nearby overpasses, following a strategy defined on the basis of the ground-track data analysis provided by NASA (Pappalardo et al., 2010; The EARLINET publishing group 2000-2010, 2014c).

EARLINET operation is coordinated such as to ensure instrument standardization and consistent retrievals within the network. This harmonization is achieved through the application of a rigorous quality-assurance program addressing both instrument performance (Matthias et al., 2004; Freudenthaler et al., 2010) and evaluation of the algorithms (Böckmann et al., 2004; Pappalardo et al., 2004).

The 14-year EARLINET database contains a large data set of the aerosol lidar ratio retrieved from simultaneous and independent lidar measurements of aerosol extinction and backscatter coefficients. Moreover, this multi-wavelength database facilitates the retrieval of extinction and backscatter spectral dependence for different aerosol types after a proper layer identification and characterization. The lidar ratio is of fundamental importance for the estimation of aerosol extinction from pure backscatter lidar measurements such as those conducted by CALIOP, and the extinction and backscatter spectral dependence is valuable for the spectral conversions between laser wavelengths.

\subsection{The AERONET product}

AERONET (http://aeronet.gsfc.nasa.gov/) is a global sun photometric network with more than 250 stations, employing the CIMEL CE318 photometer as the standard instrument (Holben et al., 1998). In AERONET, the calibration is centralized and should be performed every 12 months; thus, the instrument must be sent to specific sites (in the United States or Europe) for calibration and maintenance. The AERONET measurement schedule includes direct sun measurements at several wavelengths of the solar spectrum (at 380, 440, 500, $675,870,1020$ and $1640 \mathrm{~nm}$ depending on the instrument type) as well as diffuse sky radiances at $440,675,870$ and $1020 \mathrm{~nm}$. Direct sun measurements are used to retrieve the AOD at the measured wavelengths, the Ångström exponent 
at $440 / 870 \mathrm{~nm}$ and fine- and coarse-mode optical depth at $500 \mathrm{~nm}$ (Holben et al., 2001; O'Neill et al., 2003). Direct sun and sky radiance measurements permit the retrieval of the size distribution, the complex refractive index, and the single-scattering albedo (SSA) (Dubovik and King, 2000; Dubovik et al., 2000, 2006).

\section{Methods}

In this section we describe the methods developed for the derivation of the multi-wavelength LIVAS database. LIVAS was developed based on CALIPSO observations at 532 and $1064 \mathrm{~nm}$ and includes the converted CALIPSO extinction and backscatter product from $532 \mathrm{~nm}$ to 355,1570 and $2050 \mathrm{~nm}$ (LIVAS wavelengths). For the spectral conversion from CALIPSO $532 \mathrm{~nm}$ to the LIVAS wavelengths, we used aerosol-type-dependent backscatter- and extinction-related Ångström exponents, as these were derived from groundbased measurements or suitable optical models. Specifically, for the conversions applied in LIVAS, the spectral dependence of the extinction and backscatter was considered to follow the well-known Ångström exponential law as follows:

$x_{\text {par }}\left(\lambda_{2}\right)=x_{\text {par }}\left(\lambda_{1}\right)\left(\frac{\lambda_{1}}{\lambda_{2}}\right)^{\AA_{\lambda_{1} / \lambda_{2}}}$,

where $x_{\text {par }}\left(\lambda_{2}\right)$ is the converted extinction or backscatter at $\lambda_{2}$ (either 355,1570 or $2050 \mathrm{~nm}$ ), $\AA_{\lambda_{1} / \lambda_{2}}$ is the backscatteror extinction-related Angstrom exponents and $x_{\text {par }}\left(\lambda_{1}\right)$ is the extinction or backscatter product of CALIPSO at $\lambda_{1}=$ $532 \mathrm{~nm}$. In the following, instead of extinction-related Ångström exponents and backscatter-related Ångström exponents we use the terms EAEs and BAEs, respectively, to describe the spectral dependence of the extinction and backscatter.

An overview of the data and methods followed for the derivation of the aerosol-type-dependent BAEs and EAEs is schematically illustrated in Fig. 1 and described in Sect. 3.1. The methodology for the spectral conversion of the CALIPSO Level 2 product is demonstrated through an example presented in Sect. 3.2. The section closes with the description of the processing chain followed for quality filtering and averaging the CALIPSO observations, given in Sect. 3.3.

\subsection{Derivation of spectral BAEs and EAEs}

For the derivation of the BAEs and EAEs we used different methods and data sets for the UV and IR spectral regions: BAEs and EAEs for the 532 to $355 \mathrm{~nm}$ conversion were mainly derived from the multi-wavelength EARLINET measurements of the backscatter and extinction coefficients. EARLINET measurements cannot be used for the IR conversion since the ground-based lidars of the network are spectrally limited between 355 and $1064 \mathrm{~nm}$. Thus, for converting the CALIPSO backscatter and extinction products from
$532 \mathrm{~nm}$ to 1570 and $2050 \mathrm{~nm}$, we first defined the typical size distributions and refractive indexes of the six aerosol subtypes used by CALIPSO (i.e., dust, polluted dust, smoke, marine, clean continental and polluted continental; see also Table 1 and detailed methodology in Sect. 3.1.2) and then we calculated the respective BAEs and EAEs utilizing wellknown scattering codes like the Mie code for spherical particles (Mie, 1908; Van de Hulst, 1957), as well as the T-matrix code (Mishchenko et al., 2002) and the geometric-opticsintegral-equation technique (Yang and Liou, 1996) for nonspherical particles.

The construction of representative size distributions and refractive indexes corresponding to the CALIPSO aerosol types is not a straightforward task. The ones used to estimate the optical properties of each type in the CALIPSO classification scheme are retrieved by clustering AERONET data in respective categories/aerosol types, as described in Omar et al. (2005, 2009). Although this CALIPSO aerosol model is assumed to correspond to the independently derived CALIPSO aerosol types, this is not true for all cases, mainly due to the different nature of AERONET sun photometer measurements versus CALIPSO lidar measurements used for the categorization. The main difference is that the sun photometer is incapable of providing measurements at the backscattering angle of $180^{\circ}$. For this reason we did not use the CALIPSO aerosol model for the calculation of LIVAS BAEs and EAEs in the VIS-IR spectral range and instead we used different data sets and methods, as described in detail in Sect. 3.1.2.

A different point that needs to be highlighted for LIVAS conversions is that the CALIPSO classification used for the aerosol-type-dependent conversions possibly introduces some uncertainty in the LIVAS final product, due to inconsistencies with the observed aerosol types. CALIPSO classification is based on a threshold algorithm that takes into account the layer-integrated attenuated backscatter coefficient and an approximate particulate depolarization ratio as well as the surface type (either land or ocean; Omar et al., 2009). However, these properties do not provide all the information needed for unambiguously classifying the aerosol type and, as a result, misclassifications occur frequently (e.g., Burton et al., 2013). Since for LIVAS we need to calculate BAEs and EAEs assuming that the CALIPSO aerosol types are representative of the aerosols observed, any inconsistencies in the CALIPSO classification scheme introduce inaccuracies in our results.

Summarizing, LIVAS BAEs and EAEs were measured from EARLINET for the UV-VIS conversion and they were calculated for the VIS-IR conversion. For the latter we employed characteristic size distributions and refractive indexes from AERONET data classified into the respective aerosol types using different approaches and further validated using EARLINET measurements. Moreover, for aerosol types that are not probed by either EARLINET or AERONET (e.g., marine), we utilized typical properties from the Optical 


\section{Methodology for the derivation of LIVAS BAEs and EAEs}
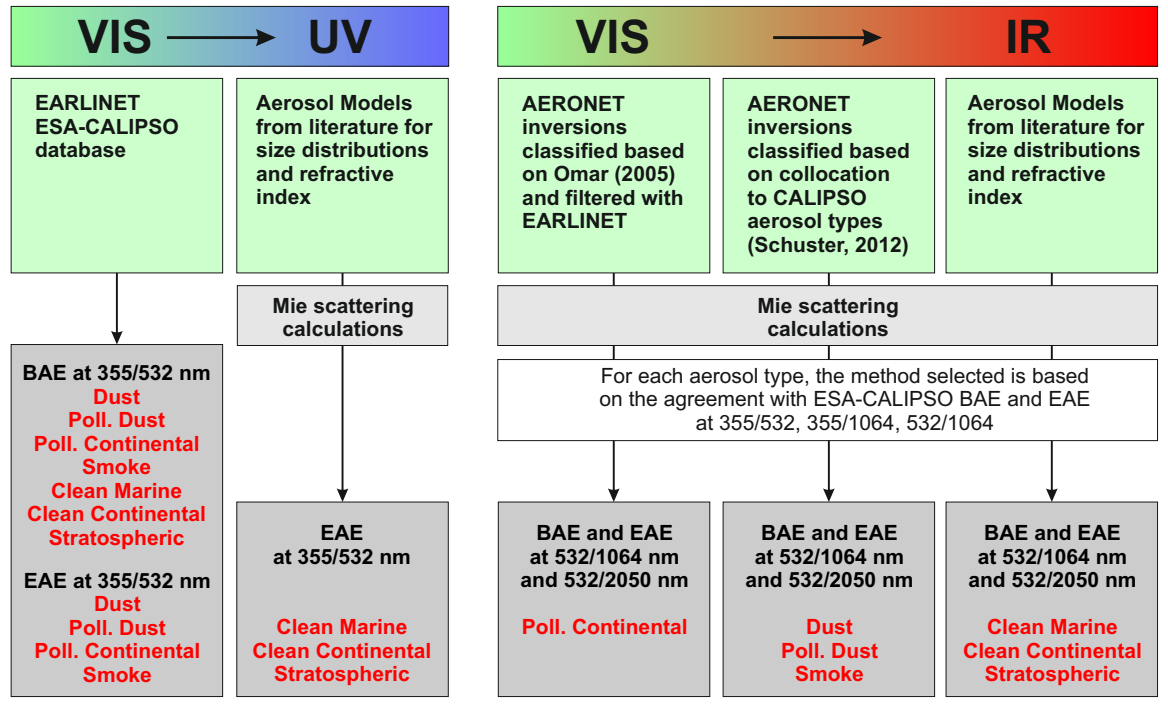

Figure 1. The data and methods used for the derivation of LIVAS BAEs and EAEs in the UV and IR spectral ranges.

Table 1. LIVAS aerosol model.

\begin{tabular}{|c|c|c|c|c|c|c|c|c|c|c|}
\hline \multirow{3}{*}{ Aerosol type } & \multicolumn{10}{|c|}{ LIVAS aerosol model } \\
\hline & \multicolumn{6}{|c|}{ Size distribution parameters } & \multicolumn{4}{|c|}{ Refractive index at $532 \mathrm{~nm}$} \\
\hline & \multicolumn{3}{|c|}{ Fine mode } & \multicolumn{3}{|c|}{ Coarse mode } & \multicolumn{2}{|c|}{ Fine mode } & \multicolumn{2}{|c|}{ Coarse mode } \\
\hline Polluted continental & 0.2 & 0.5 & 0.08 & 2.8 & 0.68 & 0.05 & 1.45 & 0.006 & 1.45 & 0.006 \\
\hline Smoke & 0.17 & 0.5 & 0.05 & 3.7 & 0.65 & 0.03 & 1.47 & 0.018 & 1.47 & 0.018 \\
\hline Clean marine & 0.16 & 0.5 & 0.22 & 2.6 & 0.72 & 1.5 & 1.41 & 0.002 & 1.36 & 0 \\
\hline Clean continental & 0.2 & 0.8 & 0.94 & 5.97 & 0.92 & 0.6 & 1.42 & 0.0023 & 1.53 & 0.008 \\
\hline
\end{tabular}

Properties of Aerosols and Clouds (OPAC) model (Hess et al., 1998) or other aerosol models from the literature. An elaborated description of our methodology for the UV-VIS and VIS-IR spectral regions is given in Sect. 3.1.1 and 3.1.2, respectively.

\subsubsection{BAEs and EAEs in UV-VIS spectral region}

For the conversion of CALIPSO aerosol backscatter and extinction from 532 to $355 \mathrm{~nm}$, the aerosol-type-dependent BAEs and EAEs were derived from the EARLINET database. Specifically, we used the database developed within the project EARLINET's Spaceborne-related Activity during the CALIPSO mission (ESA-CALIPSO; Wandinger et al., 2011). ESA-CALIPSO is an ESA-funded study aimed to establish an aerosol database from the classification of EARLINET observations performed during nearby CALIPSO overpasses with respect to the aerosol type. The methodology followed and the objectives of ESA-CALIPSO are described in Wandinger et al. (2011). In brief, during ESA-CALIPSO a large number of EARLINET observations was utilized to develop an aerosol classification scheme over Europe and to determine the respective type-dependent BAEs and EAEs, together with other aerosol intensive properties. Each EARLINET measurement was inspected regarding quality (e.g., noise level) and the occurrence of distinct aerosol layers. For each selected layer, an air-mass transport simulation was performed to determine its origin, transport path, and age. Additional modeling tools and satellite products (e.g., fire maps) were implemented to cross-check the sources and to assign an aerosol type for each layer (Wandinger et al., 2011).

For the derivation of the UV-VIS ( 355 from $532 \mathrm{~nm}$ ) BAEs and EAEs in LIVAS, we used the measurements from more than 500 aerosol layers recorded in the ESACALIPSO database and provided by four high-performance 
Table 2. BAE and EAE for each aerosol type used in LIVAS for the conversion from 532 to $355 \mathrm{~nm}$ (VIS-UV) and from 532 to 1570 and $2050 \mathrm{~nm}$ (VIS-IR). The approaches used for their calculation are also indicated.

\begin{tabular}{|c|c|c|c|c|c|c|c|c|}
\hline \multirow{3}{*}{ LIVAS aerosol type } & \multicolumn{3}{|l|}{ UV/VIS } & \multicolumn{5}{|c|}{ VIS/IR } \\
\hline & \multirow{2}{*}{ Approach used } & \multicolumn{2}{|c|}{$532 / 355 \mathrm{~nm}$} & \multirow{2}{*}{ Approach used } & \multicolumn{2}{|c|}{$532 / 1570 \mathrm{~nm}$} & \multicolumn{2}{|c|}{$532 / 2050 \mathrm{~nm}$} \\
\hline & & BAE & EAE & & BAE & EAE & BAE & EAE \\
\hline Polluted continental & ESA-CALIPSO & 1.42 & 1.24 & AERONET-Omar & 1.18 & 1.66 & 1.32 & 1.56 \\
\hline Dust & ESA-CALIPSO & 0.40 & 0.55 & AERONET-CALIPSO & 0.35 & 0.6 & 0.43 & 0.57 \\
\hline Polluted dust & ESA-CALIPSO & 0.92 & 0.71 & AERONET-CALIPSO & 0.67 & 1.14 & 0.71 & 1.07 \\
\hline Smoke & ESA-CALIPSO & 1.46 & 1.41 & AERONET-CALIPSO & 0.79 & 1.42 & 0.825 & 1.34 \\
\hline $\begin{array}{l}\text { Clean } \\
\text { marine }\end{array}$ & $\begin{array}{l}\text { ESA-CALIPSO } \\
\text { (bsc) } \\
\text { Sayer et al. (2012) } \\
\text { (ext) }\end{array}$ & 0.50 & 0.78 & Sayer et al. (2012) & 0.74 & 0.39 & 0.81 & 0.38 \\
\hline $\begin{array}{l}\text { Clean } \\
\text { continental }\end{array}$ & $\begin{array}{l}\text { ESA-CALIPSO (bsc) } \\
\text { OPAC (ext) }\end{array}$ & 1.20 & 1.31 & OPAC & 1.15 & 1.28 & 1.64 & 1.27 \\
\hline Stratospheric & $\begin{array}{l}\text { ESA-CALIPSO (bsc) } \\
\text { Deshler et al. (1993), } \\
\text { Wandinger et al. (1995) } \\
\text { (ext) }\end{array}$ & 0.98 & 0.48 & Wandinger et al. (1995) & 1.36 & 1.33 & 1.38 & 1.49 \\
\hline
\end{tabular}

EARLINET stations, namely the stations of Athens, Leipzig, Potenza and Thessaloniki. The final BAEs and EAEs were calculated by averaging the measurements collected for each aerosol type. These are presented in the left side of Table 2 for backscatter (bsc) and extinction (ext).

The EARLINET measurements included in ESACALIPSO regarding clean marine, clean continental and stratospheric aerosol particles were limited for a reliable statistical analysis. The calculation of BAEs was possible, but for EAEs this was not the case (mainly due to Raman lidar constraints regarding the overlap that prohibits extinction retrievals for lower marine atmospheric layers and regarding inadequate Raman returns from the stratosphere). For the aforementioned types, aerosol models provided in the literature were used in order to calculate the EAEs. Specifically, we used the maritime model introduced in Sayer et al. (2012) for clean marine aerosols, the OPAC model for clean continental aerosols and the stratospheric model of Wandinger et al. (1995) and Deshler et al. (1993) for stratospheric aerosols. From these models, typical size distributions and refractive indexes were retrieved and the BAEs and EAEs were calculated via the application of the Mie theory (Mie, 1908; Van de Hulst, 1957). The results are provided in Table 2 (left column).

\subsubsection{BAEs and EAEs in VIS-IR spectral region}

ESA-CALIPSO is mainly limited to the VIS-UV spectral region. For the VIS-IR conversions in LIVAS, we used typical size distributions and refractive indexes for each aerosol type derived from AERONET data or models, i.e., OPAC or other aerosol models in the literature. Scattering simulations were then applied for each aerosol type for the complete spectral range of LIVAS (i.e., 355, 532, 1064, 1570, $2050 \mathrm{~nm}$ ). The criterion for selecting between different approaches for each aerosol type was the consistency of the calculations in the UV-VIS spectral region with the ESA-CALIPSO measurements, which were the reference for any conversion made in LIVAS. More specifically, we checked the consistency of our calculations with ESA-CALIPSO for the 532-355 nm EAEs and the 532-355, 355-1064 and 532-1064-nm BAEs.

The different approaches for the derivation of the typical microphysical properties in the LIVAS aerosol model are described in the following.

AERONET-Omar: AERONET data were categorized with respect to the CALIPSO aerosol types based on the classification method introduced by Omar et al. (2005, 2009), utilized for the construction of the CALIPSO aerosol model as described above. The difference in our approach for the LIVAS aerosol model was that for each aerosol type a consistency check with the ESA-CALIPSO data was first performed: each AERONET measurement was categorized under a specific aerosol type with the Ångström exponent at $355 / 532 \mathrm{~nm}$ and the lidar ratios at 355 and $532 \mathrm{~nm}$ were computed (using the phase function and the SSA provided by AERONET). Then, we rejected the cases in which the aforementioned calculated optical properties were not within the range of the typical ESA-CALIPSO values for the respective aerosol type. From the constrained data set, the average size distribution and refractive index were produced for each aerosol type and subsequently used as input in scattering calculations to produce the spectral BAEs and EAEs in the VISIR spectral range. The method was expected to derive consistent microphysics with ESA-CALIPSO at the UV-VIS range 
and thus the results for the VIS-IR spectral range would be consistent.

For the scattering calculations, the well-known Mie code (Mie, 1908; Van de Hulst, 1957) was applied for all the aerosol types except the non-spherical particles of dust and polluted dust, where the T-matrix code and the geometricoptics-integral-equation technique were utilized instead. More specifically, for the non-spherical scattering calculations we employed the code of Dubovik et al. (2006), which utilizes the T-matrix method for particles of size parameter $\left(\frac{2 \times \pi \times \text { radius }}{\text { wavelength }}\right)$ smaller than $20-30$ and the geometricoptics-integral-equation technique for larger particles, with size parameter of up to $\sim 625$. The non-spherical particles were considered as mixtures of spheroids with aspect ratios defined by an aspect-ratio distribution, and pre-computed lookup tables were utilized, allowing for fast calculations. We considered that the non-spherical particles of dust and polluted dust over their entire size range have the same aspect ratio distribution as the one provided for dust in Dubovik et al. (2006), which was shown to reproduce successfully the laboratory measurements of mineral dust scattering properties by Volten et al. (2001).

AERONET-CALIPSO: AERONET and CALIPSO collocated and synchronized measurements were collected, following the collocation method introduced in Schuster et al. (2012). More specifically, the spatial collocation required the CALIPSO overpass to be closer than $80 \mathrm{~km}$ from the AERONET station and the measurements to take place with maximum $30 \mathrm{~min}$ difference. From the collocated measurements, only those with a single CALIPSO aerosol subtype in the atmospheric column were considered. The AERONET data for these cases were subsequently classified based on the aerosol type provided by the collocated CALIPSO measurements. Scattering calculations were applied to each of the AERONET size distributions and refractive indexes of the collected cases taking into account the spherical and non-spherical part of the mixture, as this was provided by AERONET for each case.

It should be highlighted here that for this method there was no distinction between spherical and non-spherical aerosol types, instead all types were considered to contain both spherical and non-spherical particles, in accordance with the AERONET product. The calculations for the spherical part were performed with the Mie code and for the nonspherical part with the Dubovik et al. (2006) code, following the methodology described above. For each type, all the collocated cases were averaged and from those measurements we derived the average values of BAEs and EAEs.

The data set was not constrained with ESA-CALIPSO as in the AERONET-Omar approach for the UV-VIS wavelengths. This was due to the fact that the specific approach aimed to deliver typical BAEs and EAEs for the aerosol types classified by the CALIPSO classification scheme itself; thus, no correspondence to the nature of the atmospheric aerosol loads was required.
OPAC: a typical size distribution and refractive index were extracted from the OPAC data set for the clean continental type, considering typical ambient conditions of $70 \%$ relative humidity. We derived the BAEs and EAEs by performing scattering calculations with the Mie code. Since for the clean continental aerosol there is little to no information from AERONET and EARLINET we had to rely on models to derive LIVAS BAEs and EAEs.

Approaches taken from the literature: the studies of Wandinger et al. (1995) and Deshler et al. (1993) provide a range of typical size distributions and refractive indexes for the stratospheric aerosol, while the maritime model of Sayer et al. (2012) provides a typical size distribution and refractive index for marine aerosol. We derived the corresponding BAEs and EAEs by performing scattering calculations with the Mie code.

\subsubsection{Final LIVAS BAEs and EAEs per aerosol type and evaluation against ESA-CALIPSO database}

As already mentioned, LIVAS BAEs and EAEs need to be consistent with ESA-CALIPSO, a reference database of measured lidar-related aerosol properties. While the UVVIS BAEs and EAEs were derived directly from the ESACALIPSO database, the VIS-IR BAEs and EAEs were calculated using the data sets and methods described in Sect. 3.1.2. To ensure consistency of our calculations with measured data, for each aerosol type we selected the VIS-IR methodology that provided compatible results with the ESACALIPSO for the UV-VIS BAEs and EAEs. In this way we ensured the best possible consistency of BAEs and EAEs for the entire spectral range.

Our final results are presented and discussed herein: Fig. 2 shows the calculated BAEs and EAEs using all the approaches described in Sect. 3.1.2 and their comparison with ESA-CALIPSO at UV-VIS. The selected approach for each aerosol type is denoted in Fig. 2 with large size symbols. Starting from the AERONET-Omar approach, we found that it performed better when compared to ESA-CALIPSO for the polluted continental type, resulting in a very good agreement for the EAE and best performance regarding the BAEs. For the other types this approach reproduced well the EAEs but the BAEs could not be reproduced such as to fit the ESA-CALIPSO acceptable range of values. Dust and polluted dust aerosols are most likely classified correctly by CALIPSO due to its polarization sensitivity (e.g., Burton et al., 2013; Amiridis et al., 2013). For this reason, we chose the AERONET-CALIPSO approach for the calculation of their BAEs and EAEs. The approach showed a relatively better agreement with ESA-CALIPSO compared to the AERONET-Omar approach, especially for the BAEs, maybe due to better filtering of the AERONET data used in the calculations for the AERONET-CALIPSO approach (Fig. 2). Overall though, we believe that the discrepancies in backscatter spectral dependence observed for most of the 

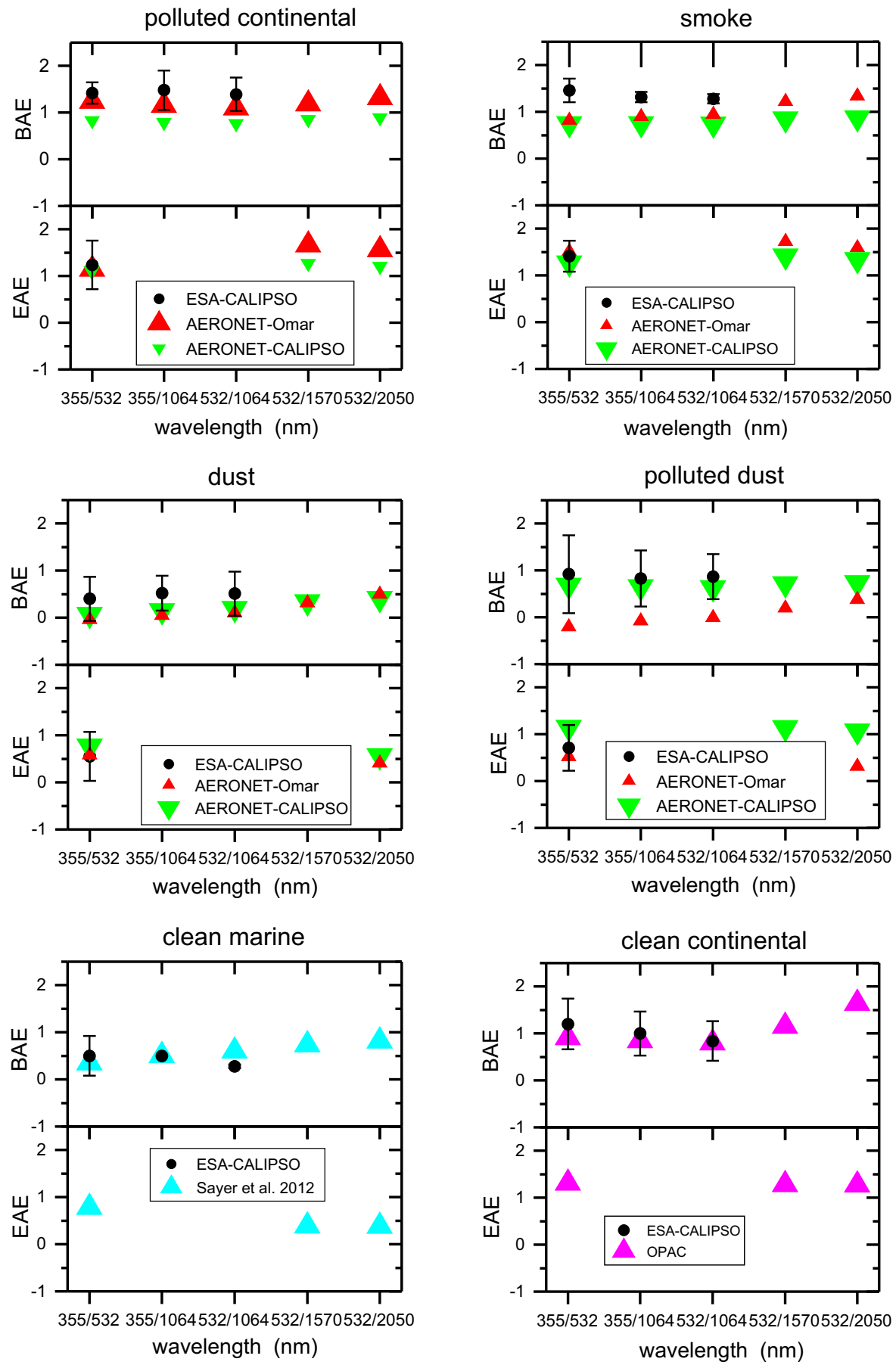

Figure 2. BAEs (upper) and EAEs (bottom) calculated with different approaches (i.e., AERONET-Omar (red triangles), AERONETCALIPSO (green triangles), Sayer et al. (2012) (cyan triangles), OPAC (pink triangles)) and validated against the ESA-CALIPSO BAEs and EAEs in VIS and UV spectral ranges (black circles). The BAEs and EAEs selected and ingested in the LIVAS aerosol model for the VIS-IR conversions, are denoted with symbols of larger size.

aerosol types are most likely due to the fact that AERONET lacks the capability to directly measure in the backscattering direction. Comparisons found in the literature between
Raman-lidar-measured and photometer-retrieved lidar ratios support this argument (e.g., Mueller et al., 2007).

Moreover, it should be noted that the evaluation of the retrieved values with ESA-CALIPSO for polluted dust is 

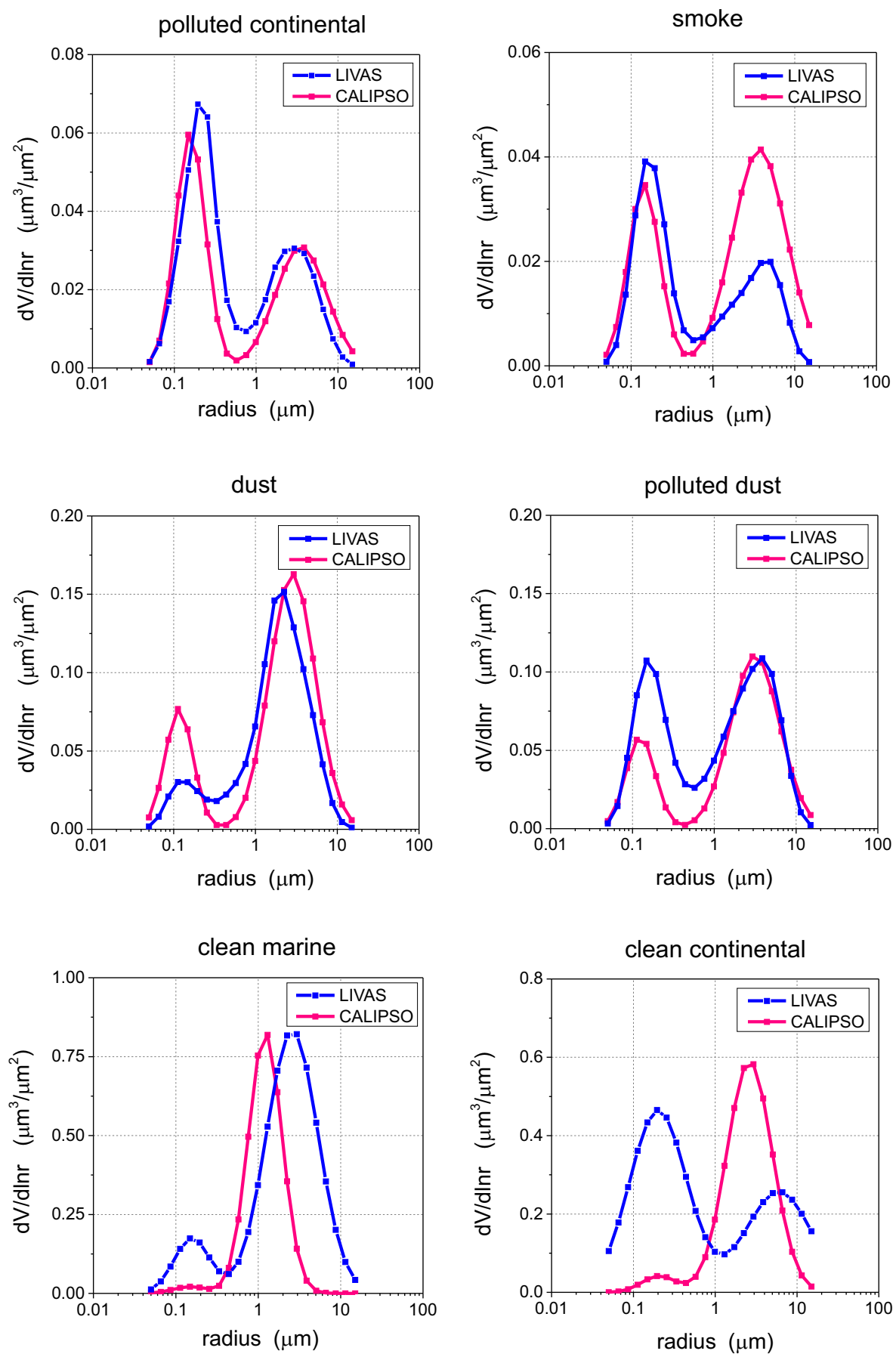

Figure 3. Comparison of the mean volume-size distributions for each aerosol type in the LIVAS (blue line) and CALIPSO (pink line) aerosol models.

only indicatory. This is because CALIPSO assumes the same properties for any kind of dust mixture (e.g., dust-smoke, dust-marine) while ESA-CALIPSO shows that the optical properties are highly variable for different dust mixtures. Specifically, ESA-CALIPSO provides intensive properties for mixtures of dust with polluted continental, smoke and marine aerosol separately and what we used here in order to compare with CALIPSO is an average of these properties.

For smoke aerosols the AERONET-CALIPSO approach showed similar results as AERONET-Omar, performing well for EAE but failing to reproduce the ESA-CALIPSO BAEs (Fig. 2). For this aerosol type we used the calculated BAEs and EAEs from the AERONET-CALIPSO approach for 

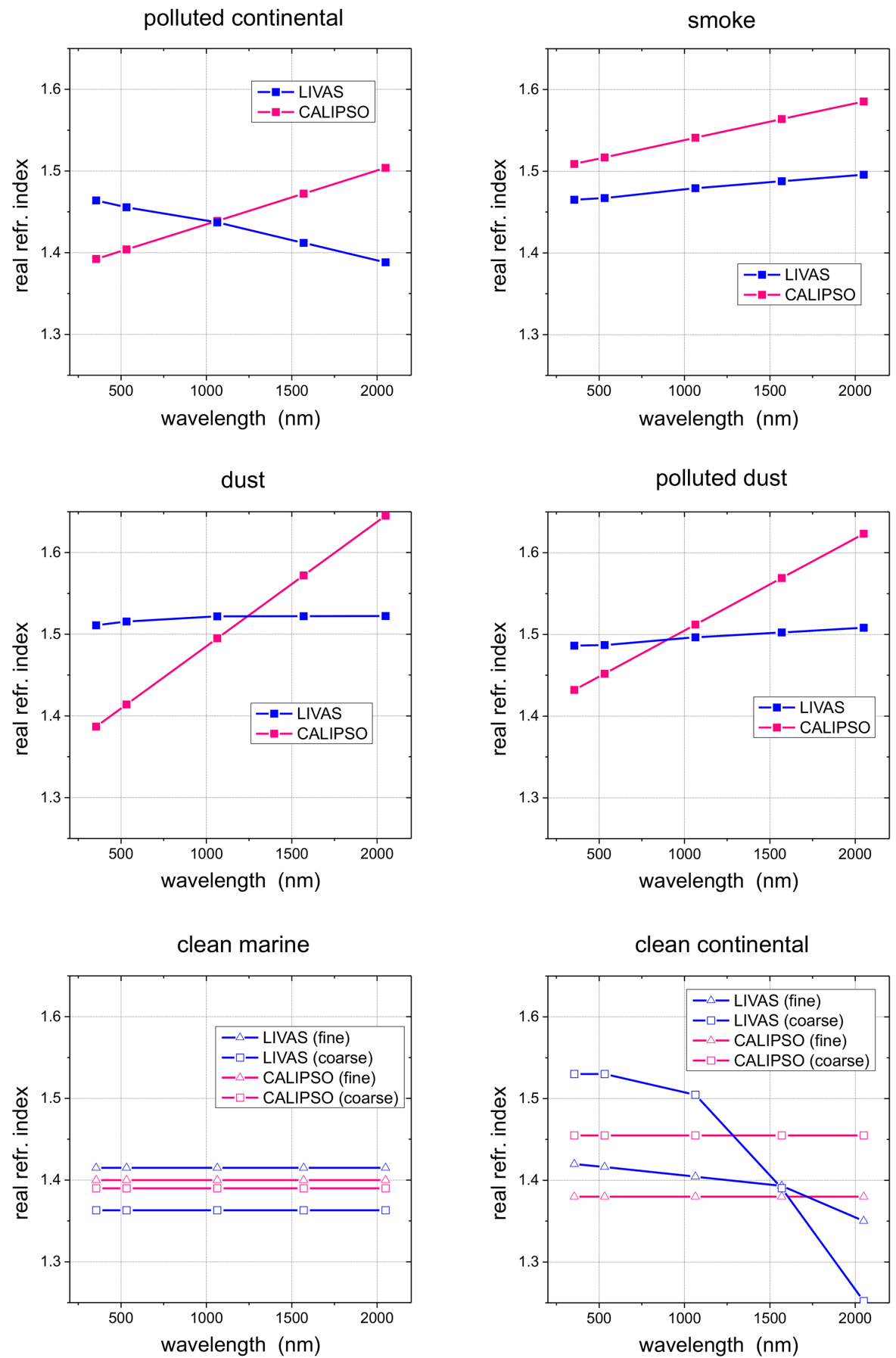

Figure 4. Comparison of the mean real part of the refractive index for each aerosol type in the LIVAS (blue line) and CALIPSO (pink line) aerosol models.

LIVAS conversions. This decision was based on the fact that the classification of smoke by CALIPSO is the most uncertain compared to the other aerosol types, as reported by Burton et al. (2013). The authors of this study reported a percentage agreement of $13 \%$ for smoke classification when comparing with airborne HSRL classification results. Smoke misclassification was also found to be the reason of the dis- crepancies between CALIPSO and AERONET reported in Schuster et al. (2012) in terms of AOD measurements. These findings indicate that the CALIPSO smoke classification may not correspond to real smoke presence. Thus, it may not be comparable with real smoke detections by EARLINET in ESA-CALIPSO. This is because the ESA-CALIPSO classification model is based on source-receptor analysis based on 

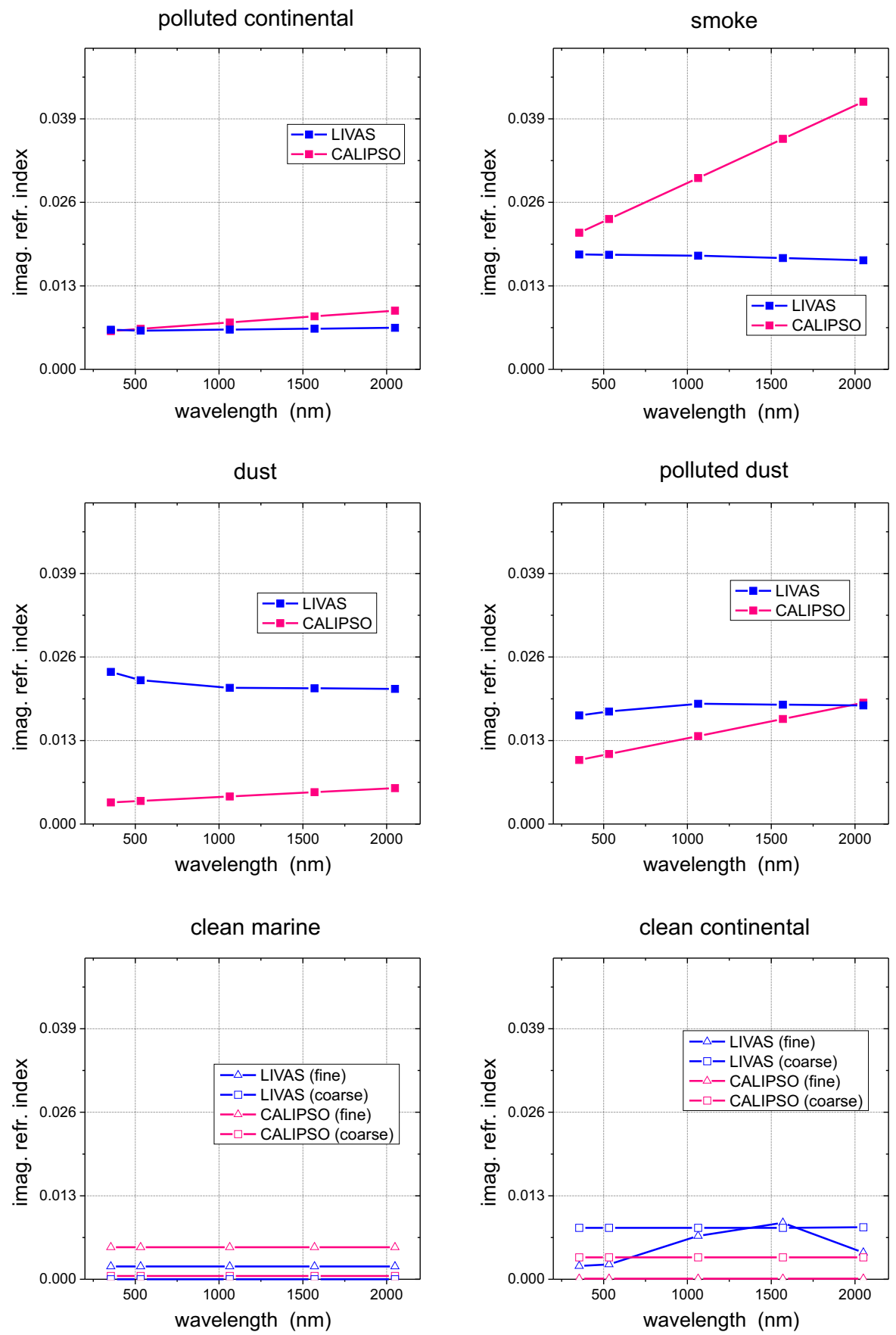

Figure 5. Comparison of the mean imaginary part of the refractive index for each aerosol type in the LIVAS (blue line) and CALIPSO (pink line) aerosol models.

model simulations of air mass advection over the stations, together with the aerosol optical properties measured by the lidar. Thus, for the smoke type we avoided using the ESACALIPSO smoke statistics.

For clean marine and clean continental aerosol, the ESACALIPSO database does not contain an adequate number of measurements to provide statistically significant averages.
Thus, for clean marine aerosol we used the size distribution and refractive index provided in the maritime model of Sayer et al. (2012) and for clean continental we used the ones provided in the OPAC database. Note that the size distribution and refractive index for clean continental aerosol from the OPAC database were considered at ambient conditions of $70 \%$ relative humidity. 

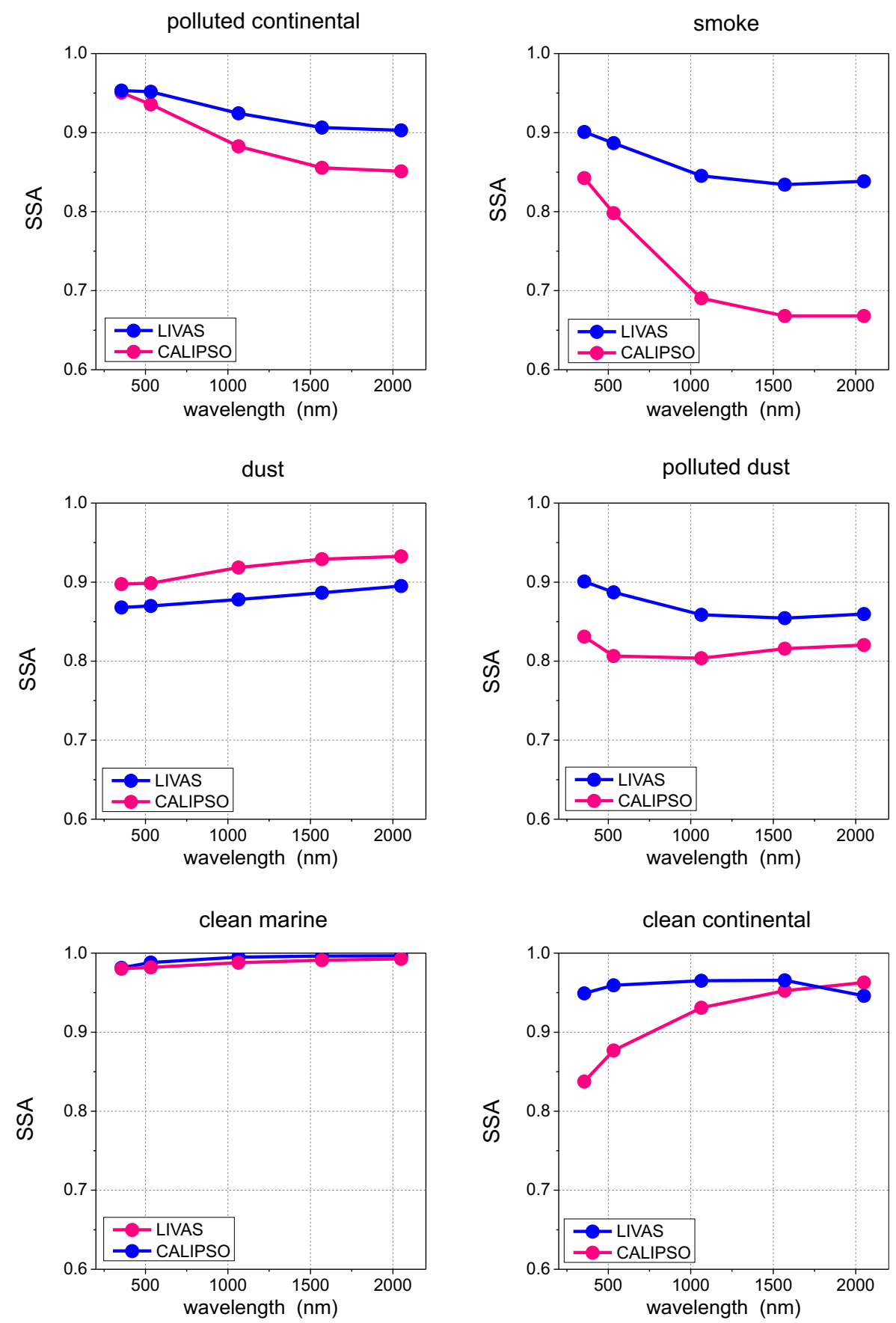

Figure 6. Comparison of the mean spectral SSA for each aerosol type in the LIVAS (blue line) and CALIPSO (pink line) aerosol models.

Finally, for the stratospheric aerosol type we used the model introduced in Deshler et al. (1993) and Wandinger et al. (1995). BAEs and EAEs were found to be in good agreement with ESA-CALIPSO values (not shown in Fig. 2).

The final aerosol-type-dependent VIS-IR BAEs and EAEs used in LIVAS are presented in the right side of Table 2 for extinction (ext) and backscatter (bsc). Overall, as seen in Fig. 2, LIVAS is compatible with ESA-CALIPSO in the VIS-UV spectral region regarding EAEs. However, the agreement with regard to the VIS-UV BAEs is not that satisfactory. For the BAEs and EAEs in the IR, another point of concern could be the extrapolation of the refractive index at the longer wavelengths, since this information is not provided from AERONET. 

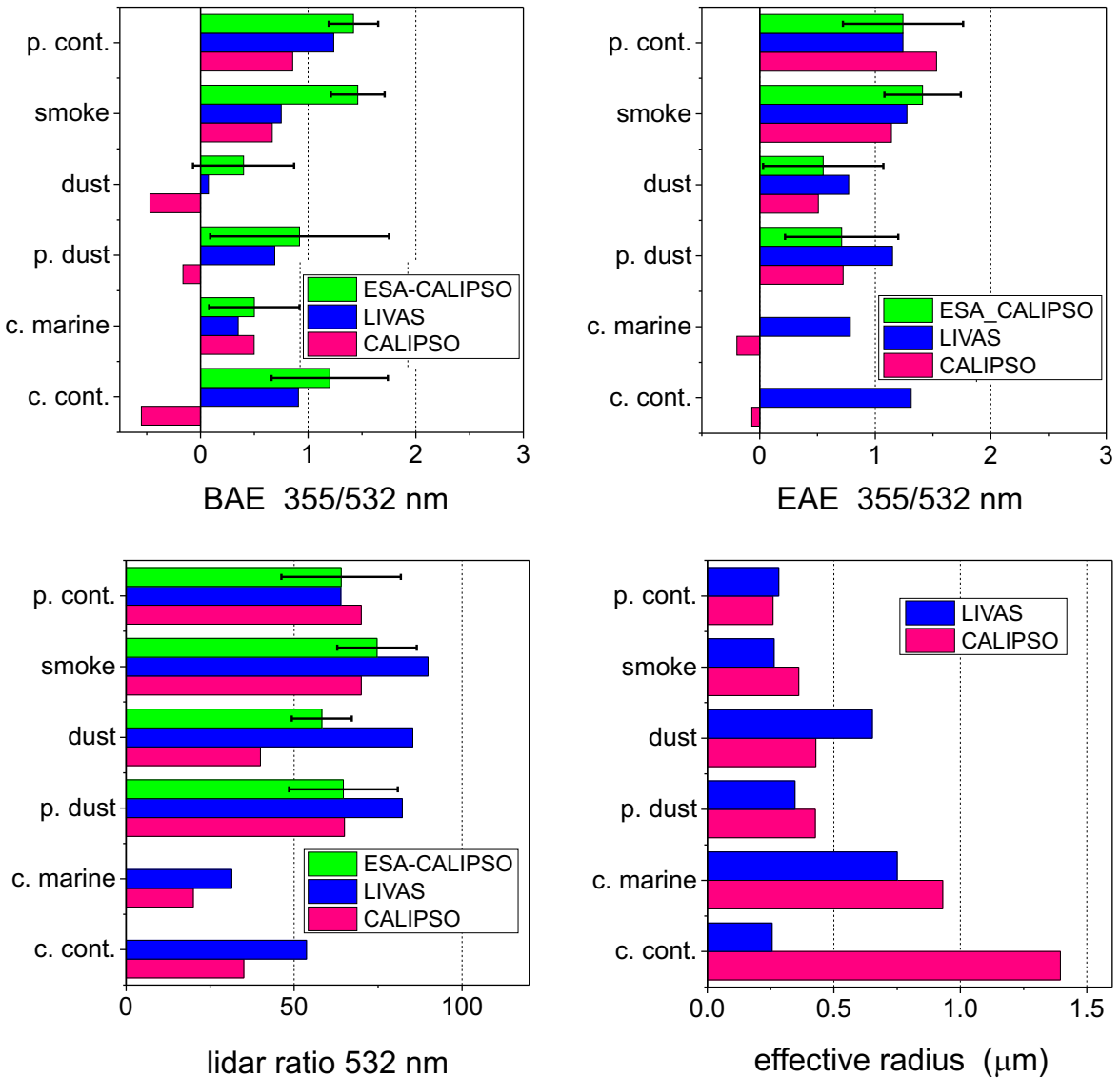

Figure 7. Comparison of LIVAS and CALIPSO with ESA-CALIPSO values for BAE at 355/532 nm (upper left), EAE at $355 / 532 \mathrm{~nm}$ (upper right), lidar ratio at $532 \mathrm{~nm}$ (lower left) and effective radius (lower right).

Table 3. LIVAS and CALIPSO LR, SSA and effective radius.

\begin{tabular}{|c|c|c|c|c|c|c|}
\hline \multirow{2}{*}{ Aerosol type } & \multicolumn{3}{|c|}{ LIVAS aerosol model } & \multicolumn{3}{|c|}{ CALIPSO aerosol model } \\
\hline & $\begin{array}{c}\text { LR at } 532 \mathrm{~nm} \\
(\mathrm{sr})\end{array}$ & $\mathrm{SSA}$ at $532 \mathrm{~nm}$ & $\begin{array}{l}\text { Effective radius } \\
\qquad(\mu \mathrm{m})\end{array}$ & $\begin{array}{c}\mathrm{LR} \text { at } 532 \mathrm{~nm} \\
(\mathrm{sr})\end{array}$ & $\mathrm{SSA}$ at $532 \mathrm{~nm}$ & $\begin{array}{c}\text { Effective radius } \\
\qquad(\mu \mathrm{m})\end{array}$ \\
\hline Polluted continental & 64 & 0.95 & 0.28 & 70 & 0.93 & 0.26 \\
\hline Smoke & 90 & 0.88 & 0.26 & 70 & 0.8 & 0.36 \\
\hline Dust & 85 & 0.87 & 0.65 & 40 & 0.9 & 0.43 \\
\hline Polluted dust & 82 & 0.89 & 0.35 & 65 & 0.8 & 0.43 \\
\hline Clean marine & 31 & 0.98 & 0.75 & 20 & 0.99 & 0.93 \\
\hline Clean continental & 54 & 0.96 & 0.26 & 35 & 0.88 & 1.4 \\
\hline
\end{tabular}

\subsubsection{Comparison of LIVAS and CALIPSO aerosol models}

The microphysical properties used for calculating the VISIR BAEs and EAEs are compared in this section with the ones of the CALIPSO aerosol model (Omar et al., 2005, 2009). Figure 3 shows the comparison of LIVAS versus CALIPSO size distributions for each aerosol type, while Figs. 4, 5 and 6 show the spectral dependence of the complex refractive index and the SSA, respectively, at LIVAS wave- lengths for the two models. Figure 7 shows the BAE and EAE at $355 / 532 \mathrm{~nm}$, the lidar ratio at $532 \mathrm{~nm}$ and the effective radius for the LIVAS and CALIPSO aerosol models compared with the ones provided in the ESA-CALIPSO database. The values of the lidar ratio at $532 \mathrm{~nm}$, the SSA at $532 \mathrm{~nm}$ and the effective radius for the two models are also provided in Table 3.

In Fig. 3 the best agreement between the LIVAS and the CALIPSO model size distributions is found for the polluted 
continental type. For smoke particles the CALIPSO model considers the same volume for fine and coarse particles, whereas the LIVAS model presents a domination of the fine mode. The latter agrees well with the averaged size distribution of smoke type provided in the Dubovik et al. (2002) AERONET 8-year climatology and is considered more typical as it is supported by other studies as well (Reid et al., 2005; Eck et al., 1999, 2003). For the dust type, the LIVAS size distribution has fewer fine particles than the CALIPSO model, in agreement with the AERONET climatology of Dubovik et al. (2002) and findings of experimental campaigns dedicated to mineral dust characterization (e.g., McConnell et al., 2008; Weinzierl et al., 2009; Müller et al., 2011; Toledano et al., 2011). For the polluted dust type both models seem to fall within the range of the large variability reported in the literature for dusty mixtures (Eck et al., 1999; Jung et al., 2010). The more pronounced fine mode in the LIVAS model resembles the size distributions of dust and pollution mixtures (Kim et al., 2007). However, an extensive discussion on the polluted dust type is avoided here since there is no clear definition of the non-dust components for this type in the CALIPSO model. LIVAS size distribution for the clean marine type is based on the maritime model of Sayer et al. (2012). Similar size distributions for marine particles are provided in other studies as well (e.g., Dubovik et al., 2002; Smirnov et al., 2002). The largest disagreement is seen for the clean continental type. We believe that the pronounced fine mode in the LIVAS size distribution from OPAC is due to the hygroscopic growth of the hydrophilic fine particles in ambient relative humidity of $70 \%$. However, the clean continental type in global CALIPSO records has a contribution on the order of $2 \%$, making this type of less importance for the LIVAS database. However, for the aerosol model, a better definition of the aerosol components of this type should be considered.

Regarding the differences on the refractive index assumed by the LIVAS and CALIPSO aerosol models, these are presented in Figs. 4 and 5, respectively, for the reader's reference. We also present a comparison of the LIVAS and CALIPSO SSA in Fig. 6. The comparison shows an overall disagreement in the SSA for the two aerosol models. We should note here that Omar et al. (2009) provide the refractive index values at 532 and $1064 \mathrm{~nm}$ and we used linear extrapolation to estimate the CALIPSO refractive indexes for the other wavelengths of LIVAS (see Figs. 4 and 5). Despite the disagreement of the SSA values, their spectral slope is similar for all the types (except the clean continental aerosol) for both models. Even more so, for polluted continental, dust, smoke, and clean marine particles the spectral slope of the SSA agrees relatively well with the corresponding ones provided in the Dubovik et al. (2002) climatology. More specifically, for the dust type the spectral slope of the SSA for both models is flatter but it closely resembles the one presented in Dubovik et al. (2002), as well as in other studies (Müller et al., 2011; Toledano et al., 2011). For smoke, the absorp- tion has to do mainly with the black carbon content and can greatly vary (Eck et al., 2003). The spectral dependence and range of LIVAS SSA values are similar to the values provided in the Dubovik et al. (2002) climatology and references therein, whereas the CALIPSO SSA has lower values which also agree with other studies (e.g., Eck et al., 1998, 2003). The polluted dust SSA spectral dependence is similar for both models but different to that of dust mixtures with smoke and pollution presented in the literature (e.g., Jung et al., 2010; Holler et al., 2003). Finally, the clean marine SSA for both models agrees very well with other studies in the literature (e.g., Dubovik et al., 2002; Hasekamp et al., 2011).

In Fig. 7, a final comparison between ESA-CALIPSO, LIVAS and CALIPSO is given in terms of BAE and EAE, lidar ratio at $532 \mathrm{~nm}$ and effective radius. BAE and EAE at $355 / 532 \mathrm{~nm}$ are not provided by Omar et al. (2009) and, instead, were calculated using the size distribution and refractive index of the CALIPSO model. For the scattering calculations we used the Mie code for the types with spherical particles and the Dubovik software for the non-spherical particles of dust and polluted dust types. The methodology was the same as the one described for the AERONET-Omar approach in Sect. 3.1.2. The lidar ratio at $532 \mathrm{~nm}$ was taken directly from what is reported in Omar et al. (2009) due to the fact that the effective radius is not given in this work, it was calculated from the size distribution for each type therein.

We need to highlight here that our focus is evaluating LIVAS BAE and EAE consistency with the ESA-CALIPSO measurements. The lidar ratio and effective radius are not used in generating the LIVAS database and are only provided here for reasons of completeness. We should make a comment though about the large LIVAS dust lidar ratio, which may be an artifact due to the aspect ratio distribution used in the non-spherical particle scattering calculations. As shown in the recent paper of Koepke et al. (2015), in order to reproduce successfully the dust optical properties, the aspect ratio distribution needs to change with particle size. This is something that indicates that more work is needed to develop a dust model oriented for spaceborne lidar applications.

Concerning the BAEs and EAEs at 355/532 nm, the maximum deviation is found for BAEs, whereas for EAEs we get an overall agreement between LIVAS, CALIPSO and ESACALIPSO. The deviation in LIVAS and CALIPSO BAEs is especially evident for the dust type (Fig. 7, upper right), possibly due to the lower effective radius produced from the large fine-mode contribution in the size distribution assumed in Omar et al. (2009). For polluted continental aerosol we get a relatively good agreement for LIVAS and ESA-CALIPSO BAEs, but this is not the case for the CALIPSO BAE. For smoke aerosol the LIVAS and CALIPSO agreement is good, but there is no consistency with ESA-CALIPSO. For clean marine aerosol all three BAEs agree well. For clean continental LIVAS BAE agrees with ESA-CALIPSO, but CALIPSO BAE is quite different. Overall, we find that the LIVAS BAEs 
are closer to the ESA-CALIPSO-measured values than the CALIPSO BAEs.

\subsubsection{Spectral conversions for other LIVAS products}

Depolarization spectral conversions were not applied in LIVAS since multi-wavelength depolarization measurements are rare and available only during experimental campaigns (Freudenthaler et al., 2009; Groß et al., 2011a, b); thus, the data set was not considered statistically significant. A singlewavelength depolarization database is provided in LIVAS using CALIPSO Level 2 particle depolarization ratio averages at $532 \mathrm{~nm}$.

Furthermore, a global cloud database is given based on CALIPSO observations at $532 \mathrm{~nm}$. With respect to clouds, the wavelength conversion is most probably of minor importance due to approximately neutral scattering behavior along the range of LIVAS wavelengths.

In addition, a database for the stratospheric features detected by CALIPSO is provided, separated to cloud and aerosol features. Specifically, the stratospheric features detected by CALIPSO were separated in polar stratospheric clouds and stratospheric aerosols using the temperature threshold technique proposed by Pitts et al. (2009). In brief, we classified the stratospheric features as polar stratospheric clouds (PSCs) for temperatures lower than $198 \mathrm{~K}$, while features of higher temperatures were classified as stratospheric aerosols. The separation was applied only for stratospheric features at latitudes greater than $54^{\circ} \mathrm{N}$ and less than $-54^{\circ} \mathrm{S}$ while for the latitudes in between the stratospheric features were considered as aerosols. This classification is not considered reliable enough and has been included in LIVAS in order to provide only a rough estimate of the stratospheric aerosol loads detected by CALIPSO. More efforts will be needed in the future for achieving a trustworthy separation of different stratospheric features. As proposed by Pitts et al. (2009), the utilization of the L1 CALIPSO product in synergy with L2 may provide a more reliable discrimination.

Finally, a set of selected scenes of specific atmospheric phenomena (e.g., dust outbreaks, volcanic eruptions, wild fires, polar stratospheric clouds) was produced. BAEs and EAEs for the selected scenes were delivered after thorough investigation of each case study, based on CALIPSOcollocated ground-based measurements that are reported in the literature. Whenever this was not possible (as for the IR conversion), the LIVAS BAEs and EAEs were used.

\subsection{Example for the spectral conversion of single CALIPSO profiles}

The obtained aerosol-type-dependent BAEs and EAEs for UV-VIS and VIS-IR were applied to the CALIPSO Level 2 product at $532 \mathrm{~nm}$ for the respective aerosol layer type inferred by the CALIPSO aerosol classification scheme. An example of the conversion from 532 to $355 \mathrm{~nm}$ is presented in
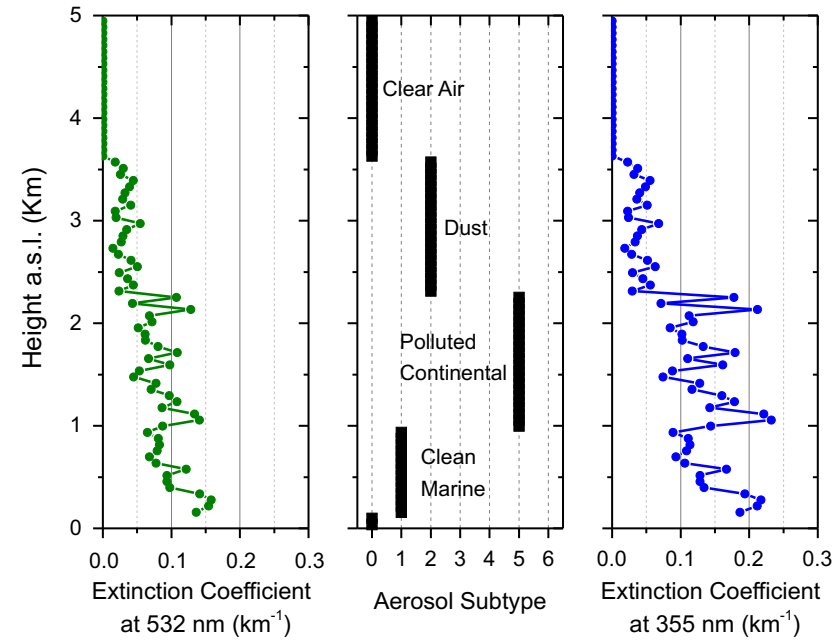

Figure 8. CALIPSO Level 2 extinction coefficient profile at $532 \mathrm{~nm}$ (left), aerosol type (center) and converted extinction coefficient at $355 \mathrm{~nm}$ (right), based on LIVAS typical EAEs. The profile example refers to 7 September 2011 (cell centroid with latitude of $37.5^{\circ}$ and longitude of $20.5^{\circ}$ ).

Fig. 8. Each CALIPSO layer in the example profile was converted from 532 to $355 \mathrm{~nm}$ using the LIVAS EAE at $355 / 532$, depending on the aerosol type retrieved by the CALIPSO aerosol classification scheme for the layer. In the example presented in Fig. 8, LIVAS EAEs for clean marine (0.78), dust (0.55) and polluted continental (1.24) types were applied to the CALIPSO extinction coefficient at $532 \mathrm{~nm}$, based on the Ångström exponential law described in Eq. (1).

\subsection{CALIPSO quality filtering and averaging processing chain}

For the production of the final LIVAS products, we used the methodology developed by the CALIPSO team for the Level 3 aerosol product, as described in Winker et al. (2013). Our algorithm was tested for reproducing the CALIPSO Level 3 product, which is an aggregation onto a global $2^{\circ} \times 5^{\circ}$ latitude-longitude grid. After the positive evaluation of the averaging procedure (not shown here), we applied it on the Level 2 CALIPSO profiles at 532 and $1064 \mathrm{~nm}$ but also on the corresponding LIVAS spectrally converted profiles at 355,1570 and $2050 \mathrm{~nm}$, in order to derive $1^{\circ} \times 1^{\circ}$ latitudelongitude-averaged vertical distributions. The vertical resolution of the LIVAS product is identical to CALIPSO Level 3, namely $60 \mathrm{~m}$ in the tropospheric region between the surface and $20 \mathrm{~km}$ and $180 \mathrm{~m}$ in the stratospheric region between 20 and $30 \mathrm{~km}$.

As input to the averaging algorithm, we used the Version 3 CALIOP Level 2 aerosol profile product, applying quality screening prior to averaging, to eliminate samples and layers that were detected or classified with very low confidence or that contained untrustworthy extinction retrievals. In brief, 


\section{LIVAS processing chain}

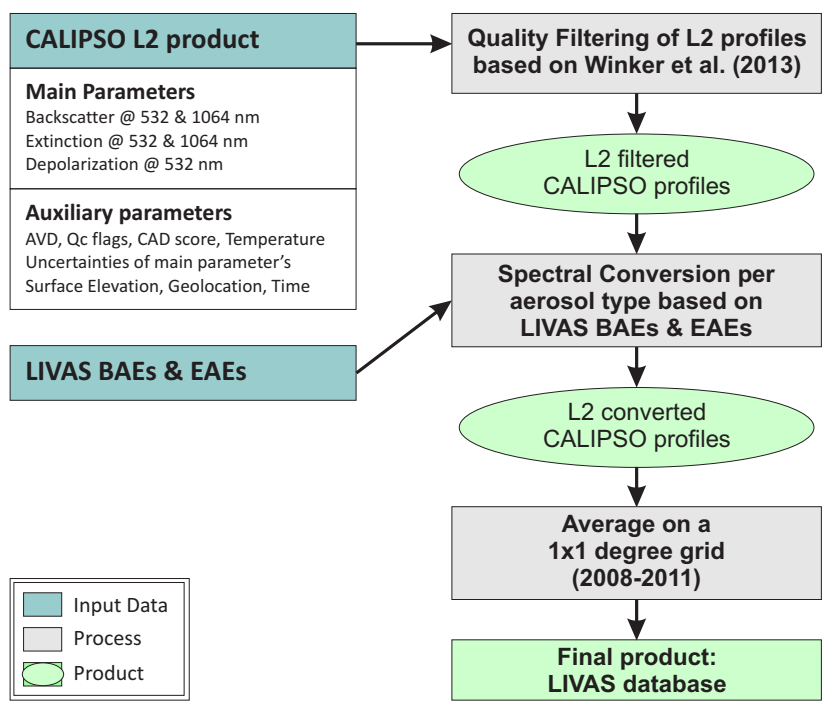

Figure 9. Schematic diagram of LIVAS processing chain.

the filters concerned the cloud-aerosol discrimination (CAD) score, extinction quality control (QC) flag, aerosol extinction uncertainty, isolated $80 \mathrm{~km}$ layer, misclassified cirrus, undetected surface-attached-aerosol low bias, large negative near-surface extinction, surface contamination beneath surface-attached opaque layer, and removal of samples below opaque cloud and aerosol layers. A detailed explanation of the methodology followed for the production of the Level 3 product and respective filtering and flags is provided in the Appendix of Winker et al. (2013). For the particle linear depolarization, an extra filter was applied in LIVAS in order to average this parameter for the same samples collected for the extinction. For that, we averaged only the particle linear depolarization CALIPSO retrievals for which the extinction uncertainty is less than $99.9 \mathrm{~km}^{-1}$, so as to maintain the same measurement sampling. For the quality screening of cloud and stratospheric feature profiles a similar methodology was followed.

In the CALIPSO Level 3 product, four types of products were generated each month, depending on sky condition and temporal coverage, and were separated into day/night segments. In LIVAS, only the "combined" product was used (Winker et al., 2013) in order to achieve a better quality of the aerosol data set regarding cloud discrimination and measurement accuracy. Moreover, beyond the mean extinction profiles for the total aerosol load, LIVAS provides mean extinction profiles at $532 \mathrm{~nm}$ for each of the six aerosol types in the CALIPSO classification scheme. Finally, the seasonal distribution of the vertical distribution of the extinction for each LIVAS cell is also provided. A schematic outline of the LIVAS processing chain is given in Fig. 9.

\section{Results and discussion}

\subsection{LIVAS products}

The final LIVAS aerosol/cloud database contains multiwavelength 4-year averaged vertical distributions and statistics for a global grid of $1^{\circ} \times 1^{\circ}$. Here, we demonstrate the LIVAS products through an example for one grid cell corresponding to our hometown, Athens, in Greece (centroid latitude of $38.5^{\circ} \mathrm{N}$ and longitude of $23.5^{\circ} \mathrm{E}$ ).

In the upper panel of Fig. 10 the aerosol extinction is given for the LIVAS lidar wavelengths, i.e., 355, 532, 1064, 1570, $2050 \mathrm{~nm}$, along with the standard deviation of the averaging at $532 \mathrm{~nm}$ (grey line). The number of observations is presented in the right panel for each plot in order to have a measure of the representativeness of the mean aerosol extinction for each cell, which depends on the available CALIPSO overpasses and corresponding samples. The maximum surface elevation over the CALIPSO overpass is given for the grid cell of interest, as obtained from the digital elevation map (DEM) used by CALIPSO. In the middle panel of Fig. 10, the mean extinction profile is given per CALIPSO aerosol type, while in the lower panel the mean extinction is given per season with the corresponding sampling/occurrences used for their production.

Additional LIVAS products are provided for particle depolarization at $532 \mathrm{~nm}$. These refer to the mean particle depolarization along with its standard deviation (Fig. 11, upper panel). Moreover, mean cloud extinction at $532 \mathrm{~nm}$ is given in LIVAS (Fig. 11, middle panel) along with the mean extinction coefficient of stratospheric features in total (Fig. 11, lower panel) but also for PSCs and aerosol particles separately.

Finally, for each grid cell a number of statistical parameters are provided in LIVAS regarding the mean, minimum and maximum surface elevations, the number of overpasses for each cell, the number of examined profiles, the samples averaged after filtering (total, aerosol, clear air), the subtype occurrence in the aerosol total observations (in percentages) and the AOD at $532 \mathrm{~nm}$ (mean, median and standard deviation).

\subsection{LIVAS AOD evaluation}

In this section an evaluation of the LIVAS climatological AOD mean values at $532 \mathrm{~nm}$ is given, using collocated AERONET AOD averages. AERONET stations included in each grid cell of $1^{\circ} \times 1^{\circ}$ were considered representative when the stations were operated for the same time period with LIVAS (2008-2011). LIVAS mean AOD was calculated by the integration of the 4-year averaged extinction profile, while AERONET AOD was calculated by averaging all available station data. A first comparison of LIVAS AODs against AERONET is presented in Fig. 12. Blue circles denote the absolute value of the difference (LIVAS mean 

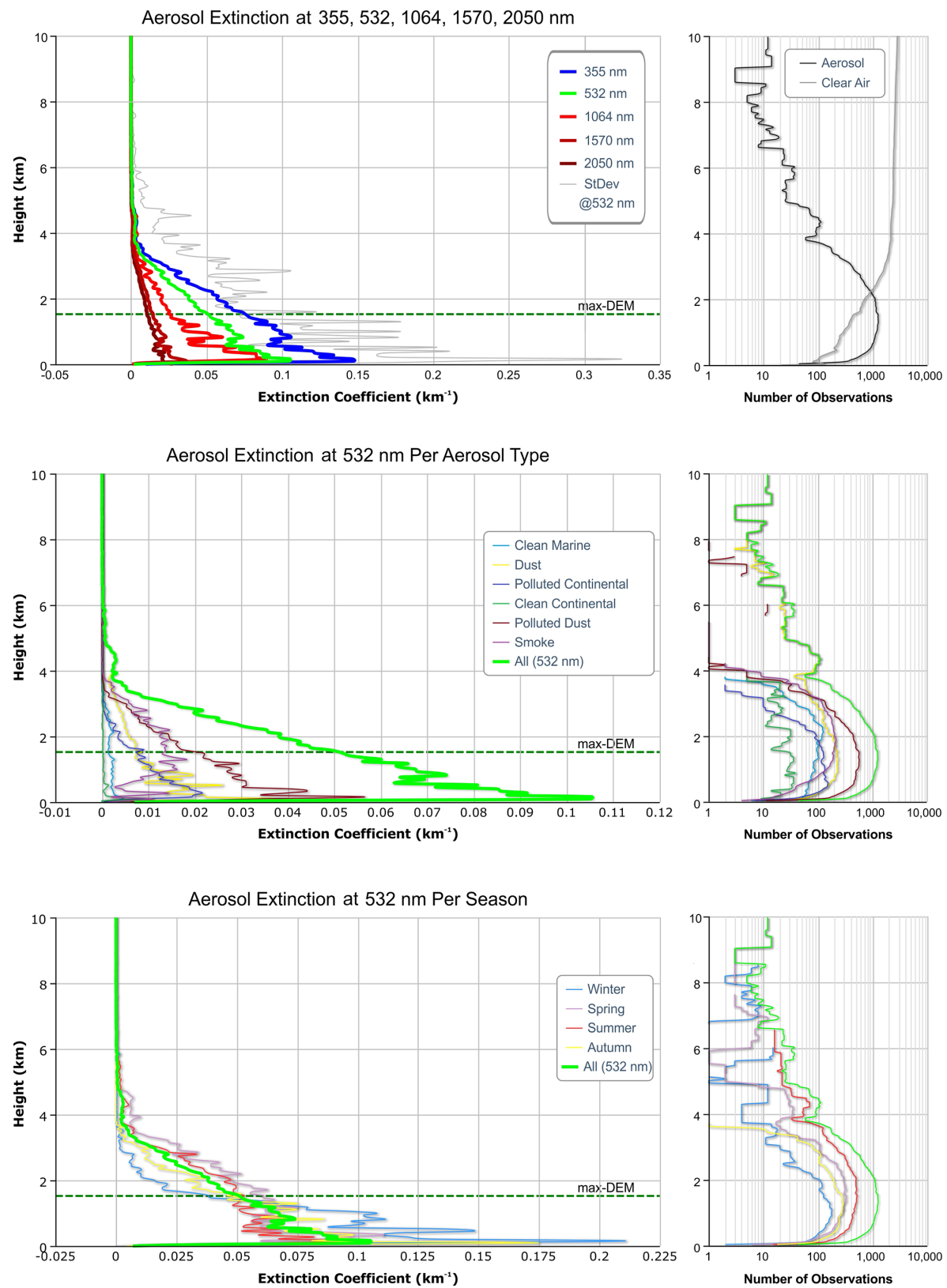

Figure 10. LIVAS aerosol extinction products. Upper panel: vertical distribution of the averaged aerosol extinction coefficient at 355, 532, 1064, 1570, and $2050 \mathrm{~nm}$ (left), number of observations used in averaging (right). Middle panel: vertical distribution of the averaged aerosol extinction coefficient per aerosol type (left), number of observations used in averaging (right). Lower panel: vertical distribution of the averaged aerosol extinction coefficient per season (left), number of observations used in averaging (right).

AOD - AERONET mean AOD), while the red crosses denote the elevation difference between the AERONET site and the mean elevation of the CALIPSO ground track. This map provides only the magnitude of biases (absolute values) to demonstrate the range of discrepancies with respect to the elevation slope. Large differences can also be attributed to specific grid cell undersampling by CALIPSO in the 4-year period, as discussed below.
Large elevation differences may cause large AOD biases since in such cases the optical path lengths monitored by AERONET and CALIPSO instruments can vary. Moreover, when CALIPSO overpasses high-slope terrains, the sampling may become inadequate for heights lower than the maximum elevation. An example of such a case is given in Fig. 13 for the AERONET station of ND_Marbel_Univ in the Philippines. CALIPSO overpasses this station over elevations ranging from 0 to $1.46 \mathrm{~km}$. The number of observations 

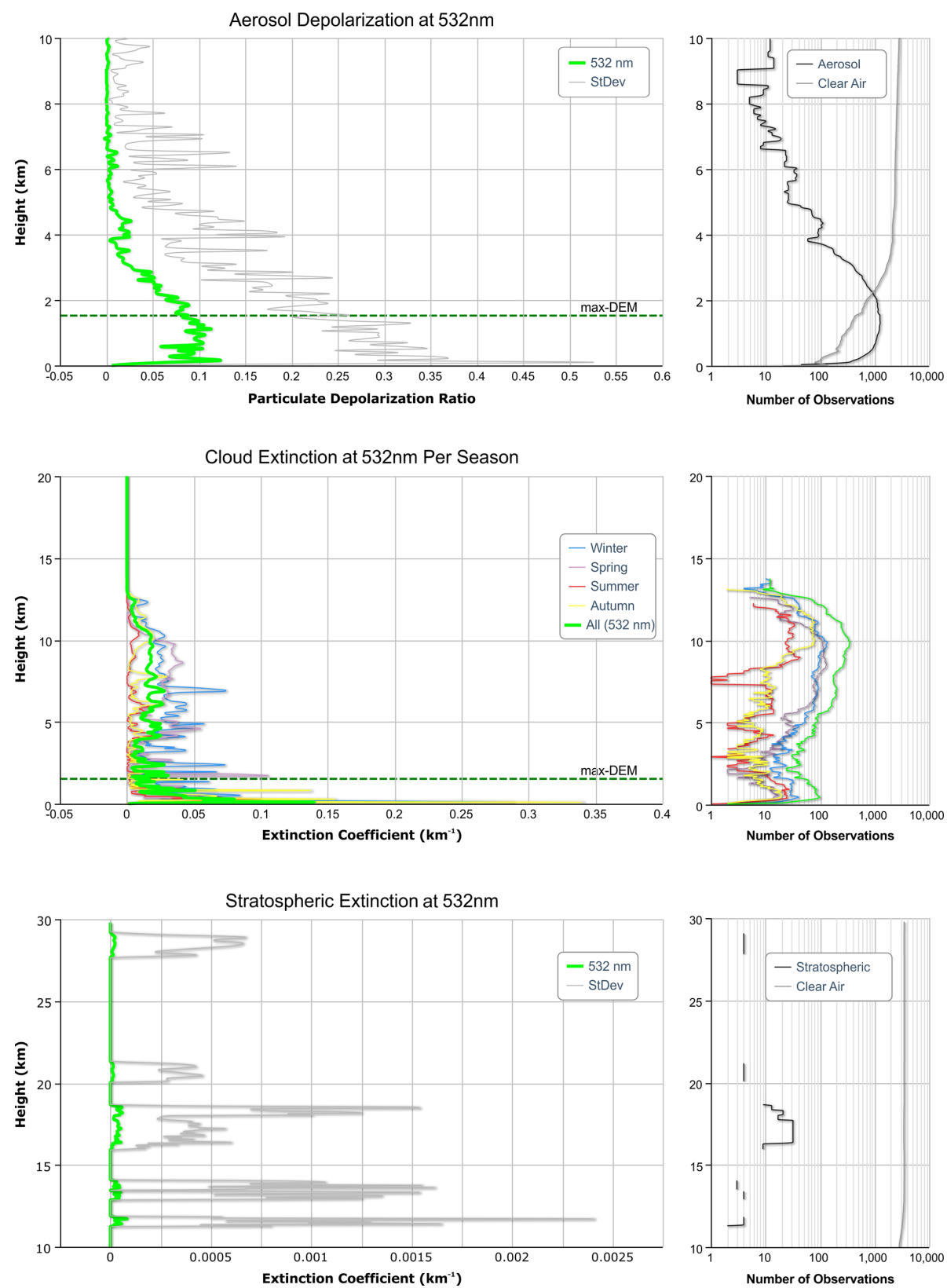

Figure 11. Additional LIVAS products. Upper panel: vertical distribution of the averaged particle depolarization at $532 \mathrm{~nm}$ (left), number of observations used in averaging (right). Middle panel: vertical distribution of the averaged cloud extinction coefficient per season (left), number of observations used in averaging (right). Lower panel: vertical distribution of the averaged stratospheric aerosol extinction coefficient (left), number of observations used in averaging (right).

for heights lower than the maximum elevation becomes very small (Fig. 13, right panel) and inadequate for statistical purposes. This undersampling affected the final averaged extinction profile as shown in the left panel of Fig. 13 for heights lower than the maximum elevation. In order to eliminate these effects from the comparison of LIVAS with AERONET, we applied on our data set the following constraints.
1. The elevation difference between the AERONET site and CALIPSO mean ground track elevation was kept below $100 \mathrm{~m}$.

2. The elevation slope in the CALIPSO overpass was constrained to be less than $400 \mathrm{~m}$.

3. CALIPSO sampling was controlled by constraining the comparison over grid cells with a large number of overpasses, i.e., over 150. 


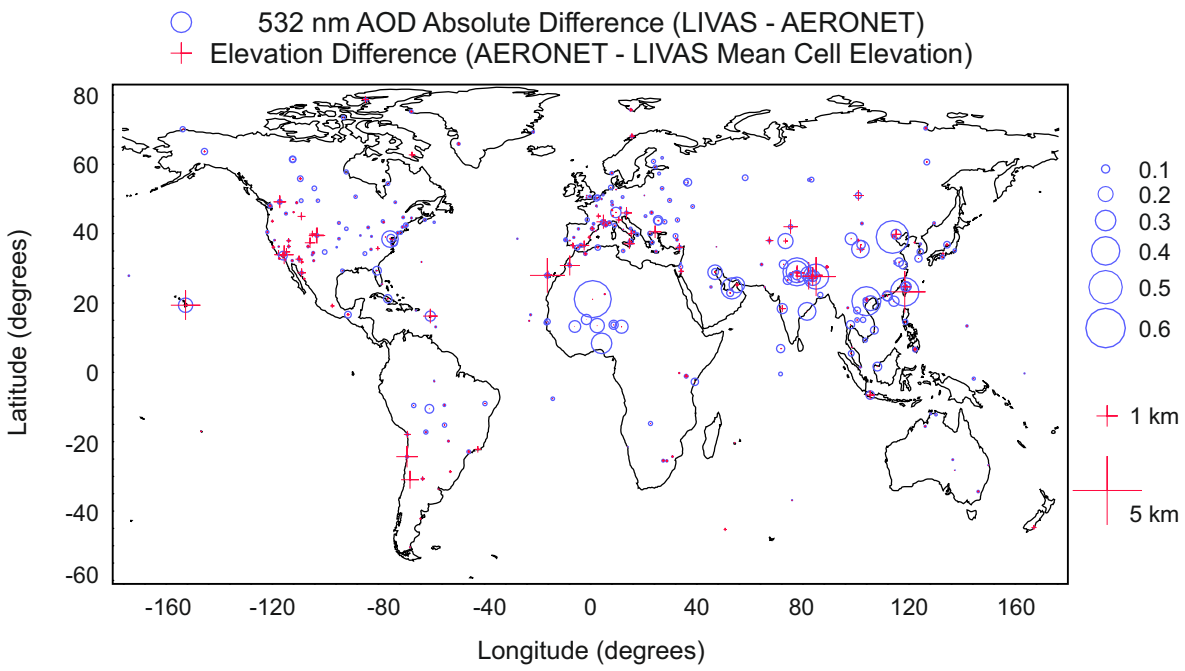

Figure 12. Spatial distribution of the $532 \mathrm{~nm}$ AOD absolute differences (absolute value of LIVAS averaged AOD minus AERONET averaged AOD) (blue circles) and of the difference between AERONET site elevation and mean grid cell elevation of CALIPSO overpasses (red crosses).
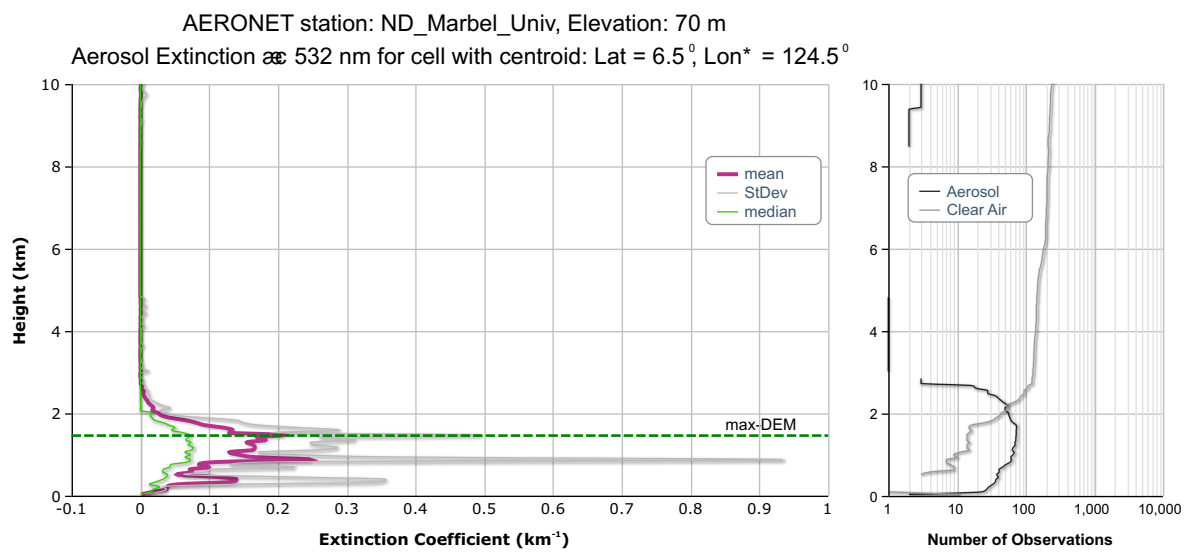

Figure 13. Example of high-slope terrain on CALIPSO overpasses for the case of the ND_Marbel_Univ AERONET station. Left panel: vertical distribution of the averaged aerosol extinction coefficient. Right panel: number of observations used in averaging.

The third constraint is considered crucial for the representativeness of the LIVAS database. As shown in Fig. 14, in approximately $30 \%$ of the global $1^{\circ} \times 1^{\circ}$ cells of the database the number of overpasses is less than 150. This undersampling along with possible high-slope terrains could cause unrealistic results.

Figure 15 presents the absolute bias of the means for our constrained data set (i.e., LIVAS mean AOD - AERONET mean AOD). For most sites the comparison reveals biases within \pm 0.1 in terms of AOD. Negative LIVAS biases lower than -0.1 (denoted in Fig. 15 with blue color) are found mostly over the Sahara, a result that may be related to possible CALIPSO underestimations for dust as already reported in the literature (e.g., Wandinger et al., 2010; Schuster et al., 2012; Tesche et al., 2013; Amiridis et al., 2013; Mamouri et al., 2013). Positive LIVAS biases larger than 0.1 denoted with the red color in Fig. 15 are mostly found over coastlines. This effect is not well understood yet. Campbell et al. (2012) found CALIPSO offsets over coastlines when comparing with the US Naval Aerosol Analysis and Predictive System (NAAPS). Recently, Kanitz et al. (2014) found a systematic overestimation of the AOD over land in coastal areas of up to a factor of 3.5. The researchers attributed the possible CALIPSO overestimation to the surface-dependent criterion (land/ocean) included in the classification scheme which may prohibit a correct classification of sea-breeze-related marine aerosol over land, leading to unrealistically high lidar ratio assumptions.

We have to mention here that the LIVAS validation presented in Fig. 15 cannot be conclusive on the aforementioned possible issues. Overall, the global LIVAS AOD agreement with AERONET AOD within 0.1 is considered a very good 


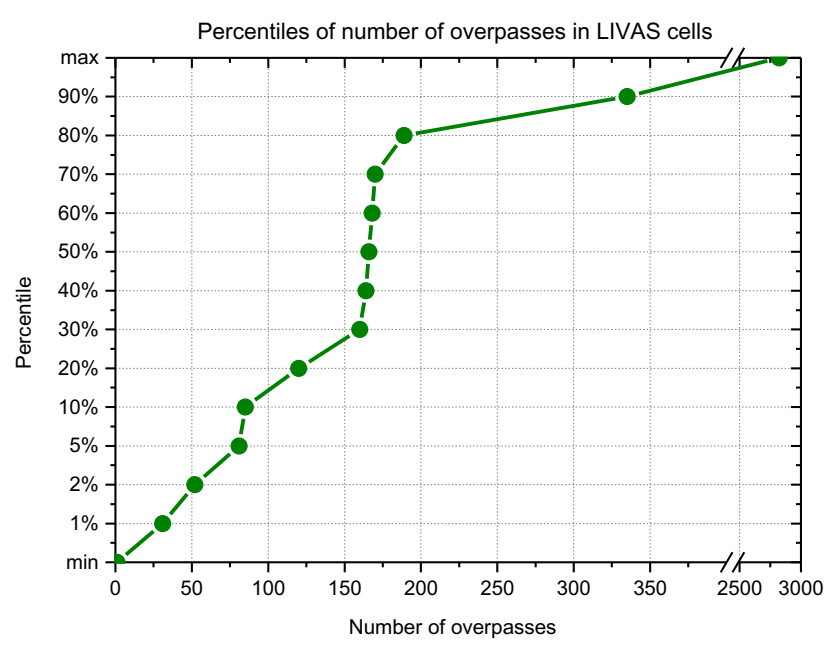

Figure 14. Percentiles of the number of overpasses in LIVAS global grid cells.

result for a 4-year product. Keeping the constrained data set for a quantitative comparison, we present in Fig. 16 scatter plots for AOD averages at the different LIVAS wavelengths. In the upper panel we show the comparison for the averaged AOD at $532 \mathrm{~nm}$ (left) and for the standard deviation of the distribution (right). A Pearson correlation coefficient of 0.86 reveals a very good agreement for the AOD at $532 \mathrm{~nm}$. The slope of the linear regression is 0.79 , showing a slight underestimation of the LIVAS AOD. Since the $532 \mathrm{~nm}$ LIVAS products come directly from CALIPSO averages, this underestimation is probably related to CALIPSO limitations (e.g., Schuster et al., 2012; Omar et al., 2013). The variability of the CALIPSO samples averaged for LIVAS is consistent with AERONET as shown in the upper right panel of Fig. 16. The LIVAS AOD at $355 \mathrm{~nm}$ (lower left panel) is also in a very good agreement with AERONET, showing similar values of Pearson's $r$ and slope as those of the $532 \mathrm{~nm}$ comparison. This result shows that the conversion of the CALIPSO extinction product from 532 to $355 \mathrm{~nm}$ using the EARLINET BAEs and EAEs is successful. Regarding the comparison at IR wavelengths (lower right panel), the results are not encouraging. LIVAS AOD at $1570 \mathrm{~nm}$ is consistent with AERONET for AODs lower than 0.1 but not for higher values where LIVAS heavily underestimates. This can be attributed to errors introduced due to the extrapolation of the AERONET AOD in the IR (note that we used AERONET AOD measurements at 440, 670, 860 and $1020 \mathrm{~nm}$ ) and/or to uncertainties introduced by the LIVAS conversion scheme in the IR.

\subsection{LIVAS web portal}

The LIVAS database is freely available under the URL: http: //lidar.space.noa.gr:8080/livas/, where the database is stored and exposed (Fig. 17). The webpage provides the complete information on the methodological approaches and instructions on the portal's usage. The data are provided in ASCII and NetCDF formats, while brief statistics and quick-view charts are projected online. The user can select to download the database via FTP, or navigate to the region of interest by using a dynamic map to select over the world grid of $1^{\circ} \times 1^{\circ}$ spatial resolution. The map provides the possibility to overlay a layer that represents the number of CALIPSO overpasses. This is considered crucial for the use of the database since only grid cells with a number of CALIPSO overpasses greater than 150 are recommended for their statistical representativeness. Moreover, the user can overlay global AODs or cloud optical depths on the map. In the example of Fig. 18, the global distribution of LIVAS AODs is presented, showing high values over well-known sources like the dust belt, India and China as well as transport paths as the one from the Sahara westward across the Atlantic.

\section{Summary and conclusions}

We presented LIVAS, a 4-year multi-wavelength global aerosol and cloud optical database that has been developed to complement existing data sets used by the ESA for instrument performance simulation of current and future spaceborne lidars as well as retrieval algorithm testing activities based on realistic atmospheric scenarios. In order to cover the different spectral domains for HSRL and IPDA lidars, the compiled database addresses the three harmonic operating wavelengths of Nd-YAG lasers (355, 532 and $1064 \mathrm{~nm}$ ) as well as typical wavelengths of IPDA lidars in the SWIR spectral domain (1570 and $2050 \mathrm{~nm})$.

When compared to AERONET, the LIVAS AOD values appeared to be realistic and representative for VIS wavelengths but also for UV wavelengths, making this database appropriate for use by ADM-Aeolus and EarthCARE. Regarding the IR conversion, however, LIVAS is not considered representative when compared to AERONET, especially for AODs higher than 0.1. We believe that LIVAS is representative in the UV due to the fact that the UV-VIS BAEs and EAEs were provided by ground-based lidar measurements of high quality, as those provided by EARLINET. Moreover, the methodology used for the application of the conversions was based on aerosol classification advances developed within the ESA-CALIPSO project. For IR , however, the BAEs and EAEs were not measured but instead retrieved from scattering simulations using typical size distributions and refractive indexes assumed for each CALIPSO aerosol type, deduced from AERONET data and aerosol models provided in the literature. Even though EARLINET was used to constrain the IR simulations, the final results were not satisfactory and more work is needed that would benefit from potential future IR ground-based measurements. However, LIVAS BAEs and EAEs were found to be more consistent with ESA-CALIPSO 


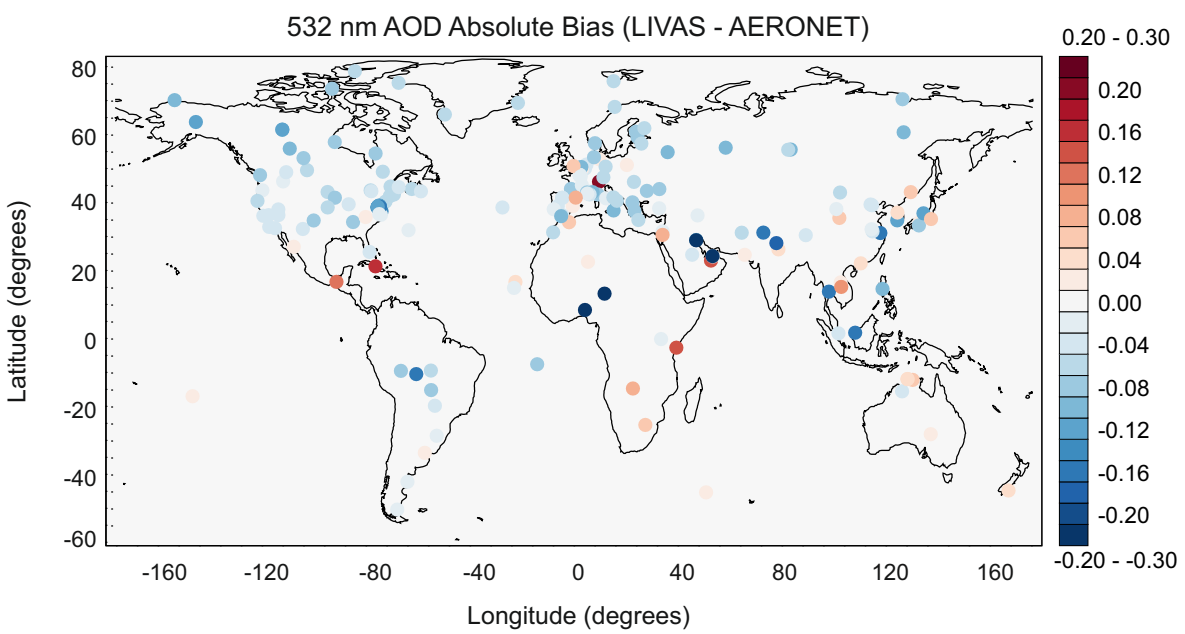

Figure 15. Spatial distribution of the $532 \mathrm{~nm}$ AOD absolute biases (LIVAS averaged AOD minus AERONET averaged AOD).
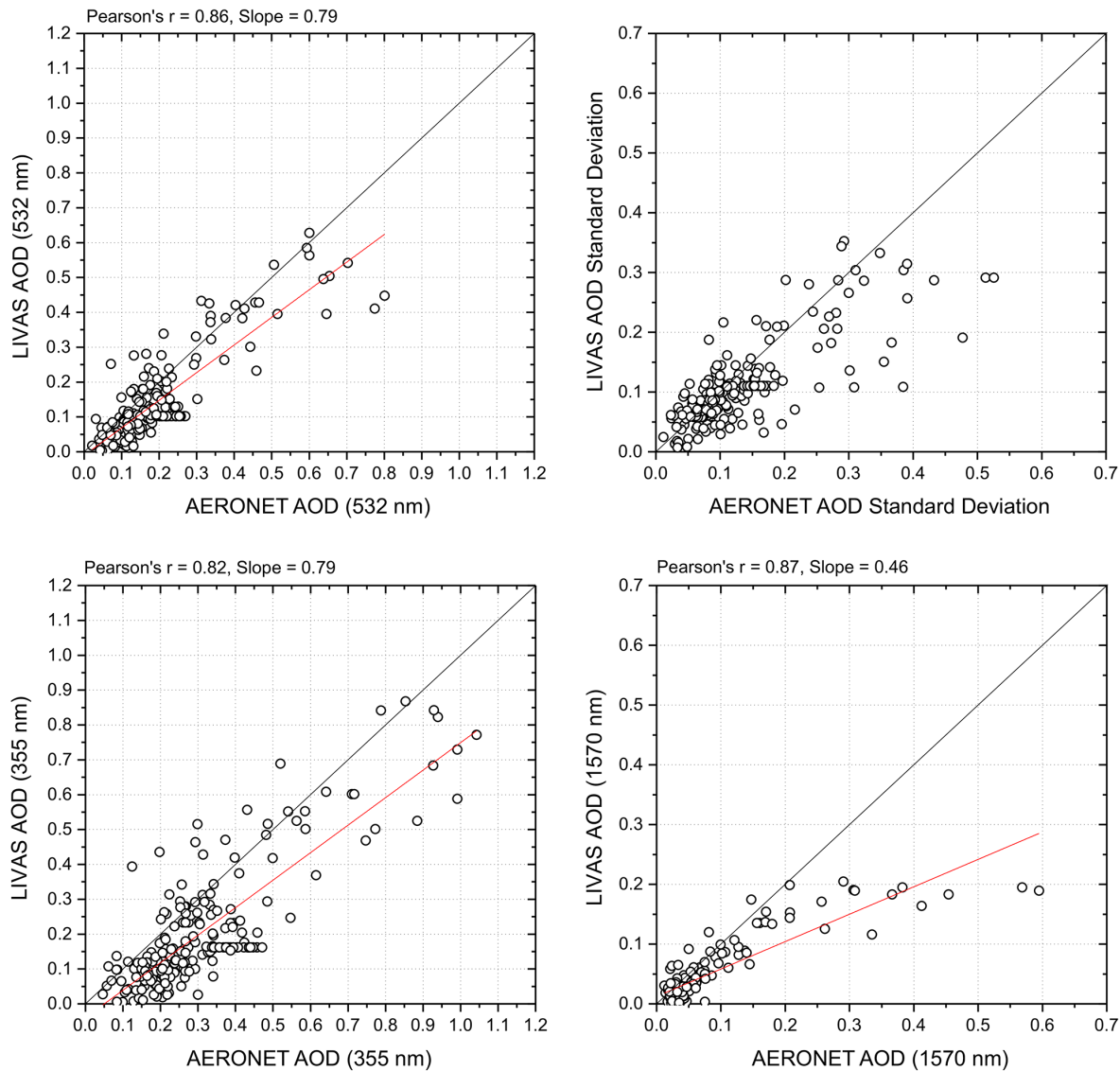

Figure 16. Upper panel: scatter plot comparisons of LIVAS AODs at $532 \mathrm{~nm}$ versus collocated AERONET Level 2 product (left) and of standard deviation of the LIVAS AODs versus standard deviation of the AERONET AODs at $532 \mathrm{~nm}$ (right). Lower panel: scatter plot comparisons of LIVAS AODs at $355 \mathrm{~nm}$ versus collocated AERONET Level 2 product (left) and of LIVAS AODs at $1570 \mathrm{~nm}$ versus collocated AERONET Level 2 product (right).

but also with the relative literature than the ones calculated with CALIPSO aerosol model.
In the future, we plan to expand LIVAS in monthlyaveraged aggregations in order to provide time series for UV lidar products. In this way, LIVAS time series could 


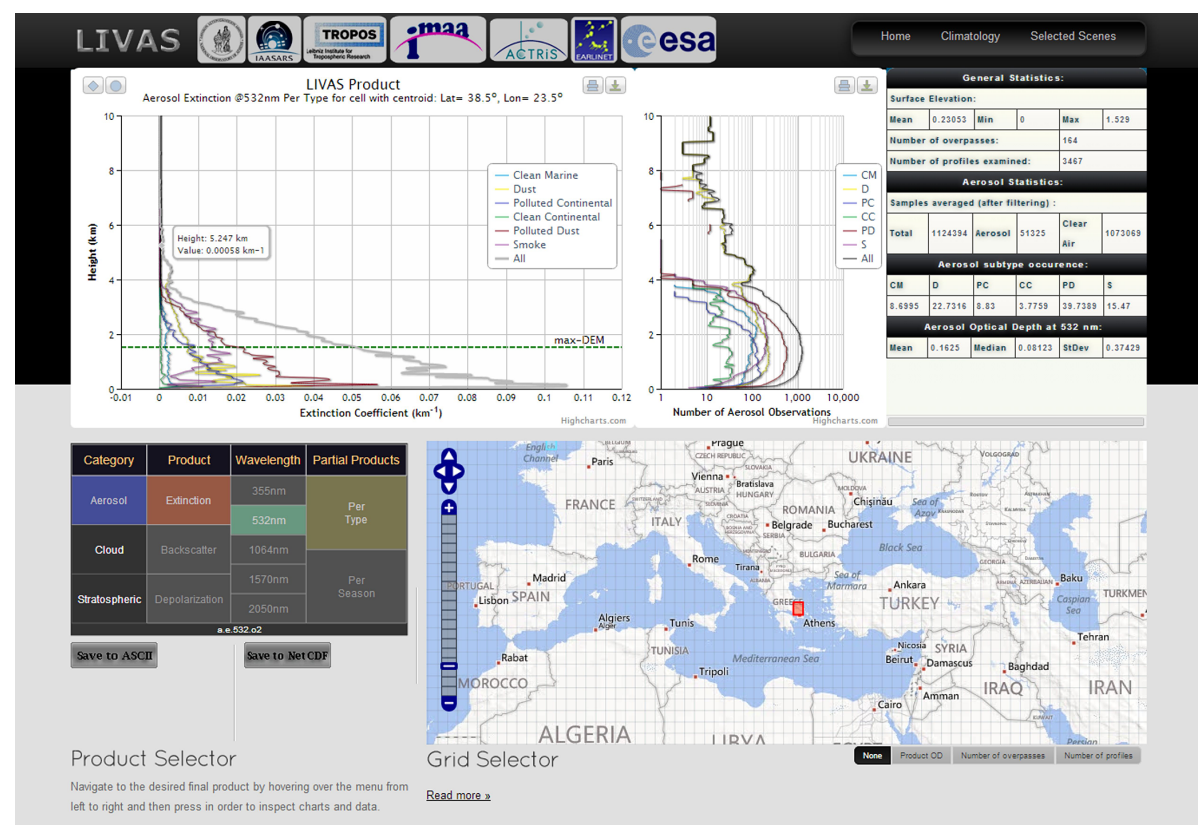

Figure 17. The LIVAS web portal.

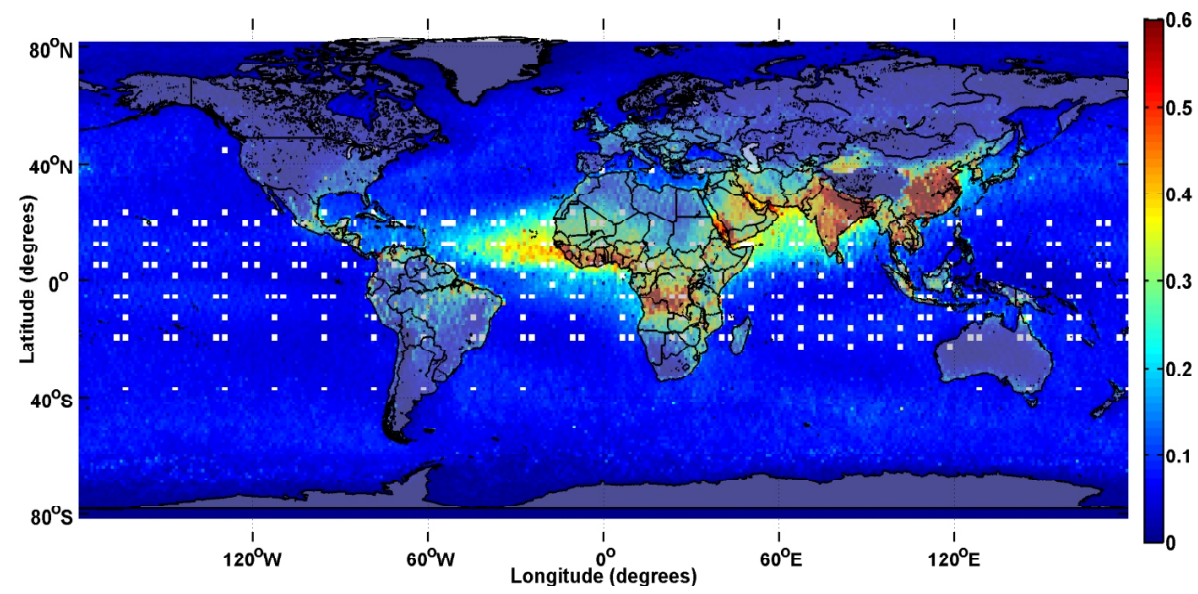

Figure 18. Global distribution of LIVAS AOD at $532 \mathrm{~nm}$.

be homogenized with future EarthCARE products for the consolidation of a multi-year aerosol/cloud multi-wavelength 4-D data set appropriate for climate studies. However, the challenges for this task are significant, due to a number of open scientific questions and related knowledge gaps. Specifically, the homogenization scheme envisaged cannot be realized without defining a common aerosol/cloud model that will be applicable to all the missions. This includes also the definition of a common aerosol/cloud classification scheme for the spaceborne products and ancillary ground-based data sets and the derivation of aerosol/cloud-type-dependent AEs for all lidar-related properties, i.e., extinction, backscatter and depolarization. It is believed that the well-established EARLINET network offers a unique opportunity to support such an effort. Several EARLINET stations operate multiwavelength Raman lidars, with most of them measuring particle depolarization as well. The network's so-called "core stations" deliver the entire CALIOP/ALADIN/ATLID parameter set, so that the BAEs and EAEs for a variety of aerosol types can be derived experimentally over a comparably long time period.

Acknowledgements. This work has been developed under the auspices of the ESA-ESTEC project: Lidar Climatology of Vertical Aerosol Structure for Space-Based LIDAR Simulation Studies (LIVAS) contract no. 4000104106/11/NL/FF/fk. The publication was supported by the European Union Seventh Framework Programme (FP7-REGPOT-2012-2013-1), in the framework of the 
project BEYOND, under grant agreement no. 316210 (BEYOND - Building Capacity for a Centre of Excellence for EO-based monitoring of Natural Disasters). The research leading to these results has received funding from the European Union Seventh Framework Programme (FP7/2007-2013) under grant agreement no. 262254 (ACTRIS), grant agreement no. 606953 and grant agreement no. 289923 - ITaRS. This research has been financed by EPAN II and PEP under the national action Bilateral, multilateral and regional R\&T cooperations (AEROVIS Sino-Greek project). This work was performed in the framework of the PROTEAS project within GSRT's KRIPIS action, funded by Greece and the European Regional Development Fund of the European Union under the O.P. Competitiveness and Entrepreneurship, NSRF 20072013 and the Regional Operational Program of Attica.

The authors acknowledge EARLINET for providing aerosol lidar profiles available under the World Data Center for Climate (WDCC) (The EARLINET publishing group 2000-2010, 2014a, $\mathrm{b}, \mathrm{c}, \mathrm{d}, \mathrm{e})$. We thank the AERONET PIs and their staff for establishing and maintaining the AERONET sites used in this investigation. CALIPSO data were obtained from the ICARE Data Center (http://www.icare.univ-lille1.fr/). We would like to thank Jason Tackett for his support during the algorithm development for the production of Level 3 CALIPSO products.

Edited by: M. Tesche

\section{References}

Amiridis, V., Wandinger, U., Marinou, E., Giannakaki, E., Tsekeri, A., Basart, S., Kazadzis, S., Gkikas, A., Taylor, M., Baldasano, J., and Ansmann, A.: Optimizing CALIPSO Saharan dust retrievals, Atmos. Chem. Phys., 13, 12089-12106, doi:10.5194/acp-1312089-2013, 2013.

Böckmann, C., Wandinger, U., Ansmann, A., Bösenberg, J., Amiridis, V., Boselli, A., Delaval, A., De Tomasi, F., Frioud, M., Grigorov, I., Hågård, A., Horvat, M., Iarlori, M., Komguem, L, Kreipl, S., Larchevêque, G., Matthias, V., Papayannis, A., Pappalardo, G., Rocadenbosch, F., Rodrigues, J., Schneider, J., Shcherbakov, V., and Wiegner, M.: Aerosol lidar intercomparison in the framework of the EARLINET project. 2. Aerosol backscatter algorithms, Appl. Optics, 43, 977-989, 2004.

Bösenberg, J., Matthias, V., Amodeo, A., Amoiridis, V., Ansmann, A., Baldasano, J. M., Balin, I., Balis, D., Böckmann, C., Boselli, A., Carlsson, G., Chaikovsky, A., Chourdakis, G., Comerón, A., De Tomasi, F., Eixmann, R., Freudenthaler, V., Giehl, H., Grigorov, I., Hågård, A., Iarlori, M., Kirsche, A., Kolarov, G., Komguem, L., Kreipl, S., Kumpf, W., Larchevêque, G., Linné, H., Matthey, R., Mattis, I., Mekler, A., Mironova, I., Mitev, V., Mona, L., Müller, D., Music, S., Nickovic, S., Pandolfi, M., Papayannis, A., Pappalardo, G., Pelon, J., Pérez, C., Perrone, R. M., Persson, R., Resendes, D. P., Rizi, V., Rocadenbosch, F., Rodrigues, A., Sauvage, L., Schneidenbach, L., Schumacher, R., Shcherbakov, V., Simeonov, V., Sobolewski, P., Spinelli, N., Stachlewska, I., Stoyanov, D., Trickl, T., Tsaknakis, G., Vaughan, G., Wandinger, U., Wang, X., Wiegner, M., Zavrtanik, M., and Zerefos. C.: EARLINET: A European Aerosol Research Lidar Network to Establish an Aerosol Climatology, Max-PlanckInstitut Report No. 348, 2003.
Burton, S. P., Ferrare, R. A., Vaughan, M. A., Omar, A. H., Rogers, R. R., Hostetler, C. A., and Hair, J. W.: Aerosol classification from airborne HSRL and comparisons with the CALIPSO vertical feature mask, Atmos. Meas. Tech., 6, 1397 1412, doi:10.5194/amt-6-1397-2013, 2013.

Campbell, J. R., Reid, J. S., Westphal, D. L., Zhang, J., Tackett, J. L., Chew, B. N., Welton, E. J., Shimizu, A., Sugimoto, N., Aoki, K., and Winker, D. M.: Characterizing the vertical profile of aerosol particle extinction and linear depolarization over Southeast Asia and the Maritime Continent: the 2007-2009 view from CALIOP, Atmos. Res., doi:10.1016/j.atmosres.2012.05.007, 2012.

Deshler, T., Johnson, B. J., and Rozier, W. R.: Balloonborne measurements of Pinatubo aerosol during 1991 and 1992 at $41^{\circ} \mathrm{N}$ : vertical profiles, size distribution, and volatility, Geophys. Res. Lett., 20, 1435-1438, 1993.

Dubovik, O. and King, M. D.: A flexible inversion algorithm for retrieval of aerosol optical properties from sun and sky radiance measurements, J. Geophys. Res., 105, 20673-20696, 2000.

Dubovik, O., Smirnov, A., Holben, B. N., King, M. D., Kaufman, Y. J., Eck, I., and Slutsker, T. F.: Accuracy assessments of aerosol optical properties retrieved from Aerosol Robotic Network (AERONET) Sun and sky radiance measurements, J. Geophys. Res., 105, 9791-9806, 2000.

Dubovik, O., Holben, B., Eck, T. F., Smirnov, A., Kaufman, Y. J., King, M. D., Tanré, D., and Slutsker, I.: Variability of Absorption and Optical Properties of Key Aerosol Types Observed in Worldwide Locations, J. Atmos. Sci., 59, 590-608, doi:10.1175/15200469(2002)059<0590:VOAAOP>2.0.CO;2, 2002.

Dubovik, O., Sinyuk, A., Lapyonok, T., Holben, B. N., Mishchenko, M., Yang, P., Eck, T. F., Volten, H., Muñoz, O., Veihelmann, B., van der Zande, W. J., Leon, J.-F., Sorokin, M., and Slutsker, I.: Application of spheroid models to account for aerosol particle nonsphericity in remote sensing of desert dust, J. Geophys. Res., 111, D11208, doi:10.1029/2005JD006619, 2006.

Eck, T. F., Holben, B. N., Slutsker, I., and Setzer, A.: Measurements of irradiance attenuation and estimation of aerosol single scattering albedo for biomass burning aerosols in Amazonia, J. Geophys. Res., 103, 31865-31878, 1998.

Eck, T. F., Holben, B. N., Reid, J. S., Dubovik, O., Smirnov, A., O'Neill, N. T., Slutsker, I., and Kinne, S.: Wavelength dependence of the optical depth of biomass burning, urban, and desert dust aerosols, J. Geophys. Res., 104, 31333-31349, 1999.

Eck, T. F., Holben, B. N., Reid, J. S., O’Neill, N. T., Schafer, J. S., Dubovik, O., Smirnov, A., Yamasoe, M. A., and Artaxo, P.: High aerosol optical depth biomass burning events: A comparison of optical properties for different source regions, Geophys. Res. Lett., 30, 2035, doi:10.1029/2003GL017861, 2003.

ESA: Reports for Mission Selection, The Six Candidate Earth Explorer Missions, EarthCARE - Earth Clouds, Aerosols and Radiation Explorer, ESA-SP-1279(1), 2004.

Freudenthaler, V., Esselborn, M., Wiegner, M., Heese, B., Tesche, M., Ansmann, A., Müller, D., Althausen, D., Wirth, M., Fix, A., Ehret, G., Knippertz, P., Toledano, C., Gasteiger, J., Garhammer, M., and Seefeldner, M.: Depolarization ratio profiling at several wavelengths in pure Saharan dust during SAMUM 2006, Tellus, Ser. B, 61, 165-179, doi:10.1111/j.1600-0889.2008.00396.x, 2009. 
Freudenthaler, V., Gross, S., Engelmann, R., Mattis, I., Wandinger, U., Pappalardo, G., Amodeo, A., Giunta, A., D’Amico, G., Chaikovsky, A., Osipenko, F., Slesar, A., Nicolae, D., Belegante, L., Talianu, C., Serikov, I., Linne, H., Jansen, F., Wilson, K., de Graaf, M., Apituley, A., Trickl, T., Giehl, H., and Adam, M.: EARLI09 - direct intercomparison of eleven EARLINET lidar systems, in: Proceedings of the 25th International Laser Radar Conference, St. Petersburg, Russia, 5-9 July, 891-894, 2010.

Groß, S., Tesche, M., Freudenthaler, V., Toledano, C., Wiegner, M., Ansmann, A., Althausen, D., and Seefeldner, M.: Characterization of Saharan dust, marine aerosols and a mixture of biomass burning aerosols and dust by means of multiwavelength depolarization and Raman measurements during SAMUM-2, Tellus, Ser. B, 63, 706-724. doi:10.1111/j.1600-0889.2011.00556.x, 2011a.

Groß, S., Freudenthaler, V., Wiegner, M., Gasteiger, J., Geiß, A., and Schnell, F.: Dual-wavelength linear depolarization ratio of volcanic aerosols: Lidar measurements of the Eyjafjallajökull plume over Maisach, Germany, Atmos. Environ., 48, 85-96, doi:10.1016/j.atmosenv.2011.06.017, 2011b.

Hasekamp, O., Litvinov, P., and Butz, A.: Aerosol properties over the ocean from PARASOL multi-angle photopolarimetric measurements, J. Geophys. Res., 116, D14204, doi:10.1029/2010JD015469, 2011.

Hess, M., Köpke, P., and Schult, I.: Optical properties of aerosols and clouds: the software package OPAC, B. Am. Meteorol. Soc., 79, 831-844, 1998.

Holben, B. N., Eck, T. F., Slutsker, I., Tanre, D., Buis, J. P., Setzer, A., Vermote, E., Reagan, J. A., Kaufman, Y. J., and Nakajima, T.: AERONET - A federated instrument network and data archive for aerosol characterization, Remote Sens. Environ., 66, 1-16, 1998.

Holben, B. N., Tanré, D., Smirnov, A., Eck, T. F., Slutsker, I., Abuhassan, N., Newcomb, W. W., Schafer, J. S., Chatenet, B., Lavenu, F., Kaufman, Y. J., Vande Castle, J., Setzer, A., Markham, B., Clark, D., Frouin, R., Halthore, R., Karneli, A., O'Neill, N. T., Pietras, C., Pinker, R. T., Voss, K., and Zibordi, G.: An emerging ground-based aerosol climatology: Aerosol optical depth from AERONET, J. Geophys. Res.-Atmos., 106, 12067-12097, doi:10.1029/2001JD900014, 2001.

Holler, R., Ito, K., Tohno, S., and Kasahara, M.: Wavelengthdependent aerosol single-scattering albedo: Measurements and model calculations for a coastal site near the Sea of Japan during ACEAsia, J. Geophys. Res., 108, 8648, doi:10.1029/2002JD003250, 2003.

Illingworth, A. J., Barker, H. W., Beljaars, A., Ceccaldi, M., Chepfer, H., Cole, J., Delanoë, J., Domenech, C., Donovan, D. P., Fukuda, S., Hirakata, M., Hogan, R. J., Huenerbein, A., Kollias, P., Kubota, T., Nakajima, T., Nakajima, T. Y., Nishizawa, T., Ohno, Y., Okamoto, H., Oki, R., Sato, K., Satoh, M., Shephard, M., Wandinger, U., Wehr, T., and van Zadelhoff, G.-J.: THE EARTHCARE SATELLITE: The next step forward in global measurements of clouds, aerosols, precipitation and radiation, B. Am. Meteorol. Soc., 0003-0007, doi:10.1175/BAMS-D-1200227.1, 2014.

Jung, J., Kim, Y. J., Lee, K. Y., -Cayetano, M. G., Batmunkh, T., Koo, J.-H., and Kim, J.: Spectral optical properties of longrange transport Asian dust and pollution aerosols over Northeast Asia in 2007 and 2008, Atmos. Chem. Phys., 10, 5391-5408, doi:10.5194/acp-10-5391-2010, 2010.
Kanitz, T., Ansmann, A., Foth, A., Seifert, P., Wandinger, U., Engelmann, R., Baars, H., Althausen, D., Casiccia, C., and Zamorano, F.: Surface matters: limitations of CALIPSO V3 aerosol typing in coastal regions, Atmos. Meas. Tech., 7, 2061-2072, doi:10.5194/amt-7-2061-2014, 2014.

Kim, S.-W., Yoon, S.-C., Kim, J., and Kim, S.-Y.: Seasonal and monthly variations of columnar aerosol optical properties over East Asia determined from multi-year MODIS, LIDAR, and AERONET Sun/sky radiometer measurements, Atmos. Environ., 41, 1634-1651, 2007.

Koepke, P., Gasteiger, J., and Hess, M.: Technical Note: Optical properties of desert aerosol with non-spherical mineral particles: data incorporated to OPAC, Atmos. Chem. Phys., 15, 59475956, doi:10.5194/acp-15-5947-2015, 2015.

Liu, Z., Vaughan, M., Winker, D., Kittaka, C., Getzewich, B., Kuehn, R., Omar, A., Powell, K., Trepte, C., and Hostetler, C.: The CALIPSO Lidar Cloud and Aerosol Discrimination: Version 2 Algorithm and Initial Assessment of Performance, J. Atmos. Oceanic Technol., 26, 1198-1213, doi:10.1175/2009jtecha1229.1, 2009.

Mamouri, R. E., Ansmann, A., Nisantzi, A., Kokkalis, P., Schwarz, A., and Hadjimitsis, D.: Low Arabian dust extinctionto-backscatter ratio, Geophys. Res. Lett., 40, 4762-4766, doi:10.1002/grl.50898, 2013.

Matthais, V., Freudenthaler, V., Amodeo, A., Balin, I., Balis, D., Bösenberg, J., Chaikovsky, A., Chourdakis, G., Comeron, A., Delaval, A., De Tomasi, F., Eixmann, R., Hågård, A., Komguem, L., Kreipl, S., Matthey, R., Rizi, V., Rodrigues, J. A., Wandinger, U., and Wang, X.: Aerosol lidar inter-comparison in the framework of the EARLINET project. 1 Instruments, Appl. Optics, 43, 961-976, 2004.

McConnell, C. L., Highwood, E. J., Coe, H., Formenti, P., Anderson, B., Osborne, S., Nava, S., Desboeufs, K., Chen, G., and Harrison, M. A. J.: Seasonal variations of the physical and optical characteristics of Saharan dust: Results from the Dust Outflow and Deposition to the Ocean (DODO) experiment, J. Geophys. Res., 113, D14S05, doi:10.1029/2007JD009606, 2008.

Mie, G.: Beiträge zur Optik trüber Medien, speziell kolloidaler Metallösungen, Ann. Phys., 25, 377-445, 1908.

Mishchenko, M. I., Travis, L. D., and Lacis, A. A.: Scattering, Absorption, and Emission of Light by Small Particles, Cambridge Univ. Press, New York, available at: http://www.giss.nasa. gov/ crmim/books.html (last access: 18 December 2014), ISBN: 9780521782524, 2002.

Mueller, D., Ansmann, A., Mattis, I., Tesche, M., Wandinger, U., Althausen, D., and Pisani, G.: Aerosol-type-dependent lidar ratios observed with Raman lidar, J. Geophys. Res., 112, D16202, doi:10.1029/2006JD008292, 2007.

Müller, T., Schladitz, A., Massling, A., Kaaden, N., Wiedensohler, A., and Kandler, K.: Spectral absorption coefficients and imaginary parts of refractive indices of Saharan dust during SAMUM1, Tellus, 61B, 79-95, 2011.

Omar, A. H., Won, J.-G., Winker, D. M., Yoon, S.-C., Dubovik, O., and Mc-Cormick, M. P.: Development of global aerosol models using cluster analysis of Aerosol Robotic Network (AERONET) measurements, J. Geophys. Res., 110, 2156-2202, doi:10.1029/2004JD004874, 2005.

Omar, A. H., Winker, D. M., Kittaka, C., Vaughan, M. A., Liu, Z. Y., Hu, Y. X., Trepte, C. R., Rogers, R. R., Fer- 
rare, R. A., Lee, K. P., Kuehn, R. E., and Hostetler, C. A.: The CALIPSO automated aerosol classification and lidar ratio selection algorithm, J. Atmos. Ocean. Tech., 26, 1994-2014, doi:10.1175/2009jtecha1231.1, 2009.

Omar, A. H., Winker, D. M., Tackett, J. L., Giles, D. M., Kar, J., Liu, Z., Vaughan, M. A., Powell, K. A., and Trepte, C. R.: CALIOP and AERONET aerosol optical depth comparisons: One size fits none, J. Geophys. Res.-Atmos., 118, 4748-4766, doi:10.1002/jgrd.50330, 2013.

O’Neill, N. T., Eck, T. F., Smirnov, A., Holben, B. N., and Thulasiraman, S.: Spectral discrimination of coarse and fine mode optical depth, J. Geophys. Res., 108, 4559, doi:10.1029/2002JD002975, 2003.

Pappalardo, G., Amodeo, A., Pandolfi, M., Wandinger, U., Ansmann, A., Bosenberg, J., Matthias, V., Amiridis, V., De Tomasi, F., Frioud, M., Iarlori, M., Komguem, L., Papayannis, A., Rocadenbosch, F., and Wang, X.: Aerosol lidar intercomparison in the framework of the EARLINET project. 3. Raman lidar algorithm for aerosol extinction, backscatter and lidar ratio, Appl. Optics, 43, 5370-5385, 2004.

Pappalardo, G., Wandinger, U., Mona, L., Hiebsch, A., Mattis, I., Amodeo, A., Ansmann, A., Seifert, P., Linne, H., Apituley, 5 A., Alados Arboledas, L., Balis, D., Chaikovsky, A., D’Amico, G., De Tomasi, F., Freudenthaler, V., Giannakaki, E., Giunta, A., Grigorov, I., Iarlori, M., Madonna, F., Mamouri, R.E., Nasti, L., Papayannis, A., Pietruczuk, A., Pujadas, M., Rizi, V., Rocadenbosch, F., Russo, F., Schnell, F., Spinelli, N., Wang, X., and Wiegner, M.: EARLINET correlative measurements for CALIPSO: first intercomparison results, J. Geophys. Res., 115, D00H19, doi:10.1029/2009JD012147, 2010.

Pappalardo, G., Amodeo, A., Apituley, A., Comeron, A., Freudenthaler, V., Linné, H., Ansmann, A., Bösenberg, J., D’Amico, G., Mattis, I., Mona, L., Wandinger, U., Amiridis, V., AladosArboledas, L., Nicolae, D., and Wiegner, M.: EARLINET: towards an advanced sustainable European aerosol lidar network, Atmos. Meas. Tech., 7, 2389-2409, doi:10.5194/amt-7-23892014, 2014.

Pitts, M. C., Poole, L. R., and Thomason, L. W.: CALIPSO polar stratospheric cloud observations: second-generation detection algorithm and composition discrimination, Atmos. Chem. Phys., 9, 7577-7589, doi:10.5194/acp-9-7577-2009, 2009.

Reid, J. S., Koppmann, R., Eck, T. F., and Eleuterio, D. P.: A review of biomass burning emissions part II: intensive physical properties of biomass burning particles, Atmos. Chem. Phys., 5, 799825, doi:10.5194/acp-5-799-2005, 2005.

Sayer, A. M., Smirnov, A., Hsu, N. C., and Holben, B. N.: A pure marine aerosol model, for use in remote sensing applications, $\mathrm{J}$. Geophys. Res., 117, D05213, doi:10.1029/2011JD016689, 2012.

Schuster, G. L., Vaughan, M., MacDonnell, D., Su, W., Winker, D., Dubovik, O., Lapyonok, T., and Trepte, C.: Comparison of CALIPSO aerosol optical depth retrievals to AERONET measurements, and a climatology for the lidar ratio of dust, Atmos. Chem. Phys., 12, 7431-7452, doi:10.5194/acp-12-7431-2012, 2012.

Smirnov, A., Holben, B. N., Kaufman, Y. J., Dubovik, O., Eck, T. F., Slutsker, I., Pietras, C., and Halthore, R. N.: Optical properties of atmospheric aerosol in maritime environments, J. Atmos. Sci., 59, 501-523, 2002.
Stoffelen, A., Pailleux, J., Källén, E., Vaughan, J. M., Isaksen, L., Flamant, P., Wergen, W., Andersson, E., Schyberg, H., Culoma, A., Meynart, R., Endemann, M., and Ingmann, P.: The Atmospheric Dynamics Mission for Global Wind Field Measurements, B. Am. Meteorol. Soc., 86, 73-87, 2005.

Tesche, M., Wandinger, U., Ansmann, A., Althausen, D., Müller, D., and Omar, A. H.: Ground-based validation of CALIPSO observations of dust and smoke in the Cape Verde region, J. Geophys. Res., 118, 1-14, doi:10.1002/jgrd.50248, 2013.

The EARLINET publishing group 2000-2010: Adam, M., AladosArboledas, L., Althausen, D., Amiridis, V., Amodeo, A., Ansmann, A., Apituley, A., Arshinov, Y., Balis, D., Belegante, L., Bobrovnikov, S., Boselli, A., Bravo-Aranda, J. A., Bösenberg, J., Carstea, E., Chaikovsky, A., Comerón, A., D’Amico, G., Daou, D., Dreischuh, T., Engelmann, R., Finger, F., Freudenthaler, V., Garcia-Vizcaino, D., García, A. J. F., Geiß, A., Giannakaki, E., Giehl, H., Giunta, A., de Graaf, M., GranadosMuñoz, M. J., Grein, M., Grigorov, I., Groß, S., Gruening, C., Guerrero-Rascado, J. L., Haeffelin, M., Hayek, T., Iarlori, M., Kanitz, T., Kokkalis, P., Linné, H., Madonna, F., Mamouriat, R.-E., Matthias, V., Mattis, I., Menéndez, F. M., Mitev, V., Mona, L., Morille, Y., Muñoz, C., Müller, A., Müller, D., NavasGuzmán, F., Nemuc, A., Nicolae, D., Pandolfi, M., Papayannis, A., Pappalardo, G., Pelon, J., Perrone, M. R., Pietruczuk, A., Pisani, G., Potma, C., Preißler, J., Pujadas, M., Putaud, J., Radu, C., Ravetta, F., Reigert, A., Rizi, V., Rocadenbosch, F., Rodríguez, A., Sauvage, L., Schmidt, J., Schnell, F., Schwarz, A., Seifert, P., Serikov, I., Sicard, M., Silva, A. M., Simeonov, V., Siomos, N., Sirch, T., Spinelli, N., Stoyanov, D., Talianu, C., Tesche, M., De Tomasi, F., Trickl, T., Vaughan, G., Volten, H., Wagner, F., Wandinger, U., Wang, X., Wiegner, M., and Wilson, K. M.: EARLINET all observations (2000-2010), World Data Center for Climate (WDCC), Hamburg, Germany, doi:10.1594/WDCC/EN_all_measurements_2000-2010, 2014a.

The EARLINET publishing group 2000-2010: Adam, M., AladosArboledas, L., Althausen, D., Amiridis, V., Amodeo, A., Ansmann, A., Apituley, A., Arshinov, Y., Balis, D., Belegante, L., Bobrovnikov, S., Boselli, A., Bravo-Aranda, J. A., Bösenberg, J., Carstea, E., Chaikovsky, A., Comerón, A., D’Amico, G., Daou, D., Dreischuh, T., Engelmann, R., Finger, F., Freudenthaler, V., Garcia-Vizcaino, D., García, A. J. F., Geiß, A., Giannakaki, E., Giehl, H., Giunta, A., de Graaf, M., GranadosMuñoz, M. J., Grein, M., Grigorov, I., Groß, S., Gruening, C., Guerrero-Rascado, J. L., Haeffelin, M., Hayek, T., Iarlori, M., Kanitz, T., Kokkalis, P., Linné, H., Madonna, F., Mamouriat, R.E., Matthias, V., Mattis, I., Menéndez, F. M., Mitev, V., Mona, L., Morille, Y., Muñoz, C., Müller, A., Müller, D., NavasGuzmán, F., Nemuc, A., Nicolae, D., Pandolfi, M., Papayannis, A., Pappalardo, G., Pelon, J., Perrone, M.R., Pietruczuk, A., Pisani, G., Potma, C., Preißler, J., Pujadas, M., Putaud, J., Radu, C., Ravetta, F., Reigert, A., Rizi, V., Rocadenbosch, F., Rodríguez, A., Sauvage, L., Schmidt, J., Schnell, F., Schwarz, A., Seifert, P., Serikov, I., Sicard, M., Silva, A. M., Simeonov, V., Siomos, N., Sirch, T., Spinelli, N., Stoyanov, D., Talianu, C., Tesche, M., De Tomasi, F., Trickl, T., Vaughan, G., Volten, H., Wagner, F., Wandinger, U., Wang, X., Wiegner, M., and Wilson, K. M.: EARLINET climatology (2000-2010), World Data Center for Climate (WDCC), Hamburg, Germany, doi:10.1594/WDCC/EN_Climatology_2000-2010,2014b. 
The EARLINET publishing group 2000-2010: Adam, M., AladosArboledas, L., Althausen, D., Amiridis, V., Amodeo, A., Ansmann, A., Apituley, A., Arshinov, Y., Balis, D., Belegante, L., Bobrovnikov, S., Boselli, A., Bravo-Aranda, J. A., Bösenberg, J., Carstea, E., Chaikovsky, A., Comerón, A., D’Amico, G., Daou, D., Dreischuh, T., Engelmann, R., Finger, F., Freudenthaler, V., Garcia-Vizcaino, D., García, A. J. F., Geiß, A., Giannakaki, E., Giehl, H., Giunta, A., de Graaf, M., GranadosMuñoz, M. J., Grein, M., Grigorov, I., Groß, S., Gruening, C., Guerrero-Rascado, J. L., Haeffelin, M., Hayek, T., Iarlori, M., Kanitz, T., Kokkalis, P., Linné, H., Madonna, F., Mamouriat, R.E., Matthias, V., Mattis, I., Menéndez, F. M., Mitev, V., Mona, L., Morille, Y., Muñoz, C., Müller, A., Müller, D., Navas-Guzmán, F., Nemuc, A., Nicolae, D., Pandolfi, M., Papayannis, A., Pappalardo, G., Pelon, J., Perrone, M. R., Pietruczuk, A., Pisani, G., Potma, C., Preißler, J., Pujadas, M., Putaud, J., Radu, C., Ravetta, F., Reigert, A., Rizi, V., Rocadenbosch, F., Rodríguez, A., Sauvage, L., Schmidt, J., Schnell, F., Schwarz, A., Seifert, P., Serikov, I., Sicard, M., Silva, A. M., Simeonov, V., Siomos, N., Sirch, T., Spinelli, N., Stoyanov, D., Talianu, C., Tesche, M., De Tomasi, F., Trickl, T., Vaughan, G., Volten, H., Wagner, F., Wandinger, U., Wang, X., Wiegner, M., and Wilson, K. M.: EARLINET correlative observations for CALIPSO (20062010), World Data Center for Climate (WDCC), Hamburg, Germany, doi:10.1594/WDCC/EN_Calipso_2006-2010, 2014c.

The EARLINET publishing group 2000-2010, Adam, M., AladosArboledas, L., Althausen, D., Amiridis, V., Amodeo, A., Ansmann, A., Apituley, A., Arshinov, Y., Balis, D., Belegante, L., Bobrovnikov, S., Boselli, A., Bravo-Aranda, J. A., Bösenberg, J., Carstea, E., Chaikovsky, A., Comerón, A., D’Amico, G., Daou, D., Dreischuh, T., Engelmann, R., Finger, F., Freudenthaler, V., Garcia-Vizcaino, D., García, A. J. F., Geiß, A., Giannakaki, E., Giehl, H., Giunta, A., de Graaf, M., GranadosMuñoz, M. J., Grein, M., Grigorov, I., Groß, S., Gruening, C., Guerrero-Rascado, J. L., Haeffelin, M., Hayek, T., Iarlori, M., Kanitz, T., Kokkalis, P., Linné, H., Madonna, F., Mamouriat, R.E., Matthias, V., Mattis, I., Menéndez, F. M., Mitev, V., Mona, L., Morille, Y., Muñoz, C., Müller, A., Müller, D., Navas-Guzmán, F., Nemuc, A., Nicolae, D., Pandolfi, M., Papayannis, A., Pappalardo, G., Pelon, J., Perrone, M. R., Pietruczuk, A., Pisani, G., Potma, C., Preißler, J., Pujadas, M., Putaud, J., Radu, C., Ravetta, F., Reigert, A., Rizi, V., Rocadenbosch, F., Rodríguez, A., Sauvage, L., Schmidt, J., Schnell, F., Schwarz, A., Seifert, P., Serikov, I., Sicard, M., Silva, A. M., Simeonov, V., Siomos, N., Sirch, T., Spinelli, N., Stoyanov, D., Talianu, C., Tesche, M., De Tomasi, F., Trickl, T., Vaughan, G., Volten, H., Wagner, F., Wandinger, U., Wang, X., Wiegner, M., and Wilson, K. M.: EARLINET observations related to volcanic eruptions (2000-2010), World Data Center for Climate (WDCC), Hamburg, Germany, doi:10.1594/WDCC/EN_VolcanicEruption_2000-2010, 2014d.

The EARLINET publishing group 2000-2010: Adam, M., Alados-Arboledas, L., Althausen, D., Amiridis, V., Amodeo, A., Ansmann, A., Apituley, A., Arshinov, Y., Balis, D., Belegante, L., Bobrovnikov, S., Boselli, A., Bravo-Aranda, J. A., Bösenberg, J., Carstea, E., Chaikovsky, A., Comerón, A., D’Amico, G., Daou, D., Dreischuh, T., Engelmann, R., Finger, F., Freudenthaler, V., Garcia-Vizcaino, D., García, A. J. F., Geiß, A., Giannakaki, E., Giehl, H., Giunta, A., de Graaf, M., Granados-Muñoz, M. J., Grein, M., Grigorov, I., Groß, S.,
Gruening, C., Guerrero-Rascado, J. L., Haeffelin, M., Hayek, T., Iarlori, M., Kanitz, T., Kokkalis, P., Linné, H., Madonna, F., Mamouriat, R.-E., Matthias, V., Mattis, I., Menéndez, F. M., Mitev, V., Mona, L., Morille, Y., Muñoz, C., Müller, A., Müller, D., Navas-Guzmán, F., Nemuc, A., Nicolae, D., Pandolfi, M., Papayannis, A., Pappalardo, G., Pelon, J., Perrone, M. R., Pietruczuk, A., Pisani, G., Potma, C., Preißler, J., Pujadas, M., Putaud, J., Radu, C., Ravetta, F., Reigert, A., Rizi, V., Rocadenbosch, F., Rodríguez, A., Sauvage, L., Schmidt, J., Schnell, F., Schwarz, A., Seifert, P., Serikov, I., Sicard, M., Silva, A. M., Simeonov, V., Siomos, N., Sirch, T., Spinelli, N., Stoyanov, D., Talianu, C., Tesche, M., De Tomasi, F., Trickl, T., Vaughan, G., Volten, H., Wagner, F., Wandinger, U., Wang, X., Wiegner, M., and Wilson, K. M.: EARLINET observations related to Saharan Dust events (2000-2010), World Data Center for Climate (WDCC), Hamburg, Germany, doi:10.1594/WDCC/EARLINET_SaharanDust_2000-2010, 2014e.

Toledano, C., Wiegner, M., Gross, S., Freudenthaler, V., Gasteiger, J., Müller, D., Müller, T., Schladitz, A., Weinzierl, B., Torres B., and O'Neill, N. T.: Optical properties of aerosol mixtures derived from sun-sky radiometry during SAMUM-2, Tellus 63B, 635648, doi:10.1111/j.1600-0889.2011.00573.x, 2011.

Van de Hulst, H.: Light Scattering by Small Particles, Wiley, New York, 1957.

Vaughan, J. M., Geddes, N. J., Flamant P. H., and Flesia, C.: Establishment of a backscatter coefficient and atmospheric database, DERA Report for ESA Contract no. 12510/97/NL/RE, DERA/EL/ISET/CR980139/1.0, 1998.

Vaughan, M. A., Powell, K. A., Kuehn, R. E., Young, S. A., Winker, D. M., Hostetler, C. A., Hunt, W. H., Liu, Z. Y., McGill, M. J., and Getzewich, B. J.: Fully automated detection of cloud and aerosol layers in the CALIPSO lidar measurements, J. Atmos. Ocean. Tech., 26, 2034-2050, doi:10.1175/2009jtecha1228.1, 2009.

Volten, H., Munoz, O., Rol, E., de Haan, J. F., Vassen, W., Hovenier, J. W., Muinonen, K., and Nousiainen, T.: Scattering matrices of mineral aerosol particles at $441.6 \mathrm{~nm}$ and $632.8 \mathrm{~nm}$, J. Geophys. Res., 106, 17375-17401, 2001.

Wandinger, U., Ansmann, A., Reichardt, J., and Deshler, T.: Determination of stratospheric aerosol microphysical properties from independent extinction and backscattering measurements with a Raman lidar, Appl. Optics, 34, 8315, doi:10.1364/AO.34.008315, 1995.

Wandinger, U., Tesche, M., Seifert, P., Ansmann, A., Müller, D., and Althausen, D.: Size matters: Influence of multiple scattering on CALIPSO light-extinction profiling in desert dust, Geophys. Res. Lett., 37, L10801, doi:10.1029/2010GL042815, 2010.

Wandinger U., Hiebsch, A., Mattis, I., Pappalardo, G., Mona, L., and Madonna, F.: Aerosols and Clouds: Long-term Database from Spaceborne Lidar Measurements, Executive Summary, available at: http://esamultimedia.esa.int/docs/gsp/C21487ExS. pdf (last access: 18 December 2014), ESTEC Contract 21487/08/NL/HE, 2011.

Weinzierl, B., Petzold, A., Esselborn, M., Wirth, M., Rasp, K., Kandler, K., Schütz, L., Koepke, P., and Fiebig, M.: Airborne measurements of dust layer properties, particle size distribution and mixing state of Saharan dust during SAMUM 2006, Tellus, 61B, 96-117 doi:10.1111/j.1600-0889.2008.00392.x, 2009. 
Winker, D. M., Vaughan, M. A., Omar, A., Hu, Y., Powell, K. A., Liu, Z., Hunt, W. H., and Young, S. A.: Overview of the CALIPSO mission and CALIOP data processing algorithms, J. Atmos. Ocean. Tech., 26, 2310-2323, doi:10.1175/2009JTECHA1281.1, 2009.

Winker, D. M., Tackett, J. L., Getzewich, B. J., Liu, Z., Vaughan, M. A., and Rogers, R. R.: The global 3-D distribution of tropospheric aerosols as characterized by CALIOP, Atmos. Chem. Phys., 13, 3345-3361, doi:10.5194/acp-13-3345-2013, 2013.
Yang, P. and Liou, K. N.: Geometric-optics-integral-equation method for light scattering by nonspherical ice crystals, Appl. Optics, 35, 6568-6584, 1996.

Young, S. A. and Vaughan, M. A.: The retrieval of profiles of particulate extinction from cloud-aerosol lidar infrared pathfinder satellite observations (CALIPSO) data: Algorithm description, J. Atmos. Oceanic Techn., 26, 1105-1119, doi:10.1175/2008JTECHA1221.1, 2009. 